\title{
THE EFFECT OF COVID-19 PANDEMIC ON LABOR DEMAND AND SEARCH BEHAVIOR: EVIDENCE FROM A JOB SEARCH WEBPAGE IN COSTA RICA AND GOOGLE DATA
}

\author{
EL EFECTO DE LA PANDEMIA DEL COVID-19 EN LA DEMANDA DE TRABAJO Y \\ LA CONDUCTA DE BÚSQUEDA: EVIDENCIA DE UNA PÁGINA WEB DE BÚSQUE- \\ DA DE EMPLEOS EN COSTA RICA Y DE GOOGLE DATA.
}

\section{Manuel Esteban Sánchez Gómez ${ }^{1}$}

\begin{abstract}
This paper presents estimates of how the pandemic of COVID-19 and the lockdown policies implemented in Costa Rica to contain its spread affected the firm's decision to post vacancies and workers search behavior, using data from the online job advertisement webpage buscoempleocr. Differences in Differences estimates suggest a drop of $67.2 \%$ in the inflow of vacancies posted by firms before and after the policies were implemented, relative to previous year. Results by industry states that Accommodation and Food Services, reported the highest decline in vacancy posting. By occupations, the reduction in vacancy posting was more severe for the groups of service and sales workers and elementary occupations. By location, the most affected provinces are those that i) are characterized by their touristic industries and ii) are main cities where industries are concentrated. Regarding the labor supply, there is an increase in the number of job seekers, however their search intensity might have declined during the pandemic.
\end{abstract}

KEYWORDS: LABOR DEMAND, JOB SEARCH, JOB VACANCIES, JOB SEARCH INTENSITY, COVID-19. JEL CLASSIFICATION: E24, J22, J23, J63, J64

1 Banco Central de Costa Rica, División Económica; Código postal: 10058-1000; San José, Costa Rica; sanchezgm@bccr.fi.cr 


\section{RESUMEN}

Este artículo presenta estimaciones de la pandemia del COVID-19 y los cierres implementados en Costa Rica para contener los contagios y analiza cómo afectó la decisión de las empresas de publicar vacantes, así como la conducta de búsqueda de los trabajadores, usando datos de la página web de avisos de empleo buscoempleocr. Los estimadores de Diferencias en Diferencias sugieren una caída del $67,2 \%$ en el flujo de vacantes publicadas por las firmas después de que se implementaron los cierres respecto al año anterior. Los resultados por industria indican que en las industrias de hospedaje y los servicios de alimentación reportaron la mayor caída en la publicación de vacantes. Por ocupaciones, la reducción en la publicación de vacantes fue más severa entre vendedores y en ocupaciones elementales. Por región, las provincias más afectadas fueron aquellas que se caracterizaban por su industria turística y eran ciudades principales que concentran una gran cantidad de industrias. Respecto a la oferta de trabajo, hay un incremento en el número de oferentes; sin embargo, su intensidad de búsqueda podría haber disminuido durante la pandemia.

PALABRAS CLAVE: DEMANDA DE TRABAJO, BÚSQUEDA DE EMPLEO, PUESTOS VACANTES, INTENSIDAD DE BÚSQUEDA DE EMPLEO, COVID-19

CLASIFICACIÓN JEL: E24, J22, J23, J63, J64

\section{INTRODUCTION}

Since the surge of the COVID-19 in 2020, policy makers around the world had to deal with the sanitary emergency and its impact in the economy. To contain the spread of the virus, lockdowns, mobility restrictions and social distancing measures were implemented, but these actions also generated a sudden contraction of the economic activity.

The pandemic and the policies implemented also affected the labor markets. In that sense, the International Monetary Fund (IMF) described the effects of the lockdown as "catastrophic" and it points out that the most vulnerable are the low skilled workers, which in most of the cases are the ones that cannot readapt their jobs tasks to home working (IMF, 2020b).

The main purpose of this research is to determine how the labor market participants reacted in the context of the COVID-19 crisis. In specific, this paper focuses on estimating the effect in labor demand by firms and to determine its heterogeneous response on different industries, regions, and occupations.

Moreover, this paper attempts to find some evidence on how the individuals searching in the labor market react to the crisis, by changing their search intensity, their participation in the market and their wage expectations from a match with a firm.

It is possible to explain the effects of this event in the labor market through search and matching theory (Pissarides, 2000). The pandemic and the policies implemented, can be interpreted as a supply shock that increased the job destruction rate. As a result, the number of unemployed workers increased and the tightness in the labor market declined.

From the firm's perspective, an increase in the job destruction rate caused a drop in the duration of worker's contracts and a reduction of the expected value of jobs, which leads firms to reduce the number of vacancies posted (i.e. their labor demand).

Since unemployment has increased, the bargaining power of workers is reduced, and firms are able to hire new workers at lower wages. This fact could compensate the decline in labor demand partially.

From worker's perspective, as tightness has declined, it is more difficult to find a job, since there are more competitors for any vacant. This might encourage them to decline their search intensity, suggesting a cyclical path of worker's search behavior (Elsby et al., 2015). 
The outcome in the labor market is one where the unemployment level is higher than before the supply shock, the matching efficiency declined, wages paid to workers are reduced, and the net effect on vacancies remains ambiguous.

In this context, the governments reacted by increasing the coverage and duration of the unemployment insurance for workers. Additionally, households affected by the recession has received monetary transfers to mitigate the effects of the income loss in their consumption. These policies might affect the worker's decisions regarding their job search intensity, participation in the labor market and firm's decision to post vacancies.

Moreover, Guerrieri et al. (2021) suggest that if the supply shock occurs in an economy with incomplete markets, few substitutes for some goods and services produced by industries under lockdown and the presence of a significant proportion of individuals with cash constraints, it is feasible that the initial supply shock leads into a subsequent demand shock, deepening the loses in terms of output and employment.

Firms and worker's response in labor market due to the pandemic is not a trivial question, but it is relevant. The understanding of the heterogeneity caused by this shock in the labor market allows to concentrate resources and develop policies more efficiently, to attend primarily those more affected by the crisis. In that sense, the estimation of the heterogeneous impact of labor demand among industries, occupations and regions are valuable assets for the decision making. Similarly, the findings on the response of job seekers will contribute to the develop of more appropriate policies to mitigate the negative effects of unemployment on the population.

The analysis presented in this paper is for firms and workers in Costa Rica, using data from buscoempleocr, a job online webpage from the Government. The dataset contains information of vacancies posted by firms and job seekers who uses the webpage to search jobs. Following the methodology presented in Hensvik, et al. (2021). Differences in Differences estimations were computed to determine the effect of the pandemic and the policies implemented on the level of vacancies posted by firms before and after the lockdown, relative to the previous year.

It is founded that the aggregate level of vacancies posted for the firms who uses the webpage buscoempleocr, compared before and after the lockdown relative to the previous year declined in $67.2 \%$. The industries that presented the highest drop in vacancy posting, were Accommodation and Food Service Activities (-86.0\%), Education (-82.6\%) and Administrative and Support Service Activities (-80.5\%). The estimated effects are consistent with empirical findings presented previously in Betcherman et al. (2020), Forsythe et al. (2020) and Hensvik et al. (2021).

By types of occupations, the highest drops on vacancies for service and sales workers, and elementary occupations, a result that is consistent with the IMF in their Outlook Report (IMF, 2020a) and with empirical literature on how the pandemic affected low skilled workers (Borjas \& Cassidy, 2020; Hensvik et al., 2021; Yasenov, 2020).

By regions, the estimates suggest that the provinces of Guanacaste and Limon are the ones who presented the highest decline in vacancy posting during the lockdown. Both provinces are characterized by their touristic industry due to the proximity to beaches and other natural landscapes. These results are consistent with the estimated effects by industry and occupations.

The analysis of labor demand by regions is an additional contribution of this paper to the research of the Costa Rican labor market, since there are no previous studies about the composition of the labor demand by provinces, mainly due to lack of statistics.

For workers, it was found a decline in the search intensity, measured by the average number of occupations that job seekers select as those they wish to work for. A possible explanation is that workers only focus their search for certain occupations that they might consider feasible to match. However, another plausible explanation is that they might be filtering those occupations that might have higher risk of contagion. Also, the number of job applicants in buscoempleocr increased significantly during the pandemic. 
This paper contributes to the literature of the effects of COVID-19 in labor markets, it is one of the still scarce papers that presents results for emerging economies, and the first with data of firms and workers in Costa Rica. Additionally, this paper contributes with a new dataset of job-vacancy posts, even though the dataset has some limitations, it's still useful to develop some inferences about the sample of firms and workers contained in it. A description of the dataset, their strengths and limitations are presented in Appendix A.

The paper is ordered as follows: section 2 presents the literature review and empirical evidence of the effects of COVID-19 on the labor markets; section 3 shows the chronology of the pandemic in Costa Rica and the policies implemented to contain the virus; section 4 introduces the data used in the paper while section 5 details the methodological approach used to estimate the responses of firms and workers. Section 6 presents the results for the labor demand and the heterogeneous response by industry, occupations, provinces, and the effect on search behavior. Finally, section 7 presents some concluding remarks.

\section{LITERATURE REVIEW}

The effects of the COVID-19 pandemic in the economies has been studied intensively since 2020. From a theoretical approach, Guerrieri et al. (2021) developed a model where a negative supply shock caused by the pandemic leads into an overreaction in aggregate demand, generating a greater contraction in output and employment, known as "Keynesian Supply Shock.

Similarly, Eichenbaum et al. (2020) developed an extension of the SIR epidemiological model and its implications in the economies. In their framework, epidemics generates large recession and it is recognized the existence of a tradeoff between economic damages and health damages.

Regarding to empirical contributions, Forsythe et al. (2020) found a general reduction in the level of vacancies due the pandemic in United States, with no particular differences between states or industries. Also, they found that UI claims growth more for those workers who were on occupations that cannot be done from home.

Bennedsen et al. (2020) documented the effect of the Government policies to contain the spread of COVID-19 on firms in Denmark. They found a median drop in revenue of 20\%, and firms who faced drops in revenue were more likely to ask for aid packages from Government. They also found that the firms who received aid packages to support labor tend to lay off few workers in comparison to the control group.

Hensvik et al. (2021) used data of vacancy postings and add views in Sweden to analyze the effect to COVID-19 on labor demand by firms and job search intensit The authors estimated that the proportion of occupations that can be done from home in Costa Rica is 16\% with (Saltiel, 2020) methodology, and 33\% with (Dingel \& Neiman, 2020) methodology. y of workers. They found a decline in the total inflow of vacancies of $40 \%$. By industries the estimated effect was heterogeneous, where the most affected were hotels and restaurants, entertainment, and retail. By occupations, they found that the largest decrease in the inflow of vacancies was for waiters and bartenders, dentists, and fast-food workers.

Similarly, Betcherman et al. (2020) studied the effect of lockdown on the Greek labor market, and documented a drop in employment and vacancy posting, while the unemployment remained relatively stable; this behavior might be partially explained by the policies implemented to reduce the negative effects on firms.

Regarding to job search intensity, Hensvik et al. (2021) estimated a decrease of around $15 \%$, measured by the number of clicks on job-adds after the COVID-19 outbreak. They also found that the job search has been redirected through "resilient occupations", i.e. more tele-workable occupations. 
Evidence of changes in job-search intensity in recessions has been documented by Brown and Matsa (2020). In this paper, the authors show how workers during the Great Recession reduced their job search intensity and restricted it to their commuting zone, especially if they lived in areas where the housing market was severely affected, and redirected their search through positions with requirements below their skills.

Working from home is one of the most popular policies implemented by Governments during the pandemic. If a significant proportion of jobs can be done from home, the negative effect of lockdown in the economy can be mitigated while social distancing is maintained. Moreover, how feasible is to do a certain job from home is relevant for both employers and employees in their decisions on posting vacancies and searching for jobs respectively. Dingel and Neiman (2020) found that $37 \%$ of jobs in the United States can be done from home, also jobs that can be done at home are better paid, on average. Yasenov (2020) identified groups of workers who currently can work from home in the United States, while (Hensvik et al., 2020) studied which occupations are more feasible to do from home by using the data of the American Time Use Survey.

Saltiel (2020) followed and approach similar to Dingel and Neiman (2020) for ten emerging economies and found that around $5.5 \%$ to $23 \%$ of the occupations can be done at home, a smaller proportion in comparison to United States.

Delaporte and Peña (2020) implemented the methodologies of Saltiel (2020) and Dingel and Neiman (2020) for 23 Latin American economies, and found that the proportion of workers who can do their jobs from home lies between $7 \%$ to $16 \%$ with the first methodology and from $14 \%$ to $35 \%$ with the second. In this paper, Costa Rica ${ }^{2}$ is the second economy with the highest proportion of tele-workable occupations, only surpassed by the Bahamas.

Basso et al., (2020) created a new classification of occupations based on their risk of contagion for European Countries and the United States. They found that around 50\% of the occupations are unsafe, with a considerable heterogeneity among countries. Particularly, immigrants, low skilled workers and workers in vulnerability conditions tend to be more represented in the jobs where the risk of contagion is higher.

The pandemic has affected differently certain groups of workers. Borjas and Cassidy (2020) indicated that the COVID-19 shock had more severe impact for foreign workers than for native workers in United States. Bui et al. (2020) documented that the COVID-19 pandemic has affected more the older workers (65 years or more) in comparisons with previous recessions in United States.

Regarding to gender differences, Alon et al. (2020) found that recession caused by the pandemic is affecting more severely industries where the share of female employment is higher, and since the lockdown measures demanded an increase in time devoted to take care children and relatives, the unemployment for females has increased more than in other recessions, increasing the gender inequalities in labor market of the United States.

The use of alternative and contemporaneous data sources of high frequency and relatively easy access has been required to obtain answers about how the pandemic has affected the economies. For example, Shen (2020) uses data from Google Trends to estimate the effect of the policies implemented in Singapore to reduce the spread of COVID-19 on mobility and job search intensity. Similarly, Fetzer et al. (2020) used the same source to study how economic anxiety expands in the context of a pandemic.

2 The authors estimated that the proportion of occupations that can be done from home in Costa Rica is 16\% with (Saltiel, 2020) methodology, and 33\% with (Dingel \& Neiman, 2020) methodology. 


\section{BACKGROUND: THE COVID-19 IN COSTA RICA}

The first case of COVID-19 detected in Costa Rica was on March 6th, the Government rapidly adopted strict policies since March 13th to contain the spread of the virus, such as social distancing, home working for $80 \%$ of public employees (and private when possible), closure of borders, travel restrictions, cancellation of school classes, banned of massive activities, closure of hotels, restaurants, national parks, churches, movie theaters, among others.

The policies implemented reduced significantly the mobility of people in places such as parks, workplaces, retail stores among others, an increased the time spent at home, as it can be inferred from the Google Mobility Reports presented in figure 1. As a result of the rapid response from Government, the number of positive cases was below one thousand the last week of May. By that time, the Government started to reopen the economy gradually, easing the travel restrictions and the social distancing measures, however, by the middle of June, the number of cases started to increase exponentially in the country (figure 2).

By the end of June, the number of positive cases was 3.459 and the Government declared community contagion in the Central Region. The easing in the restrictions was stopped and Government adopted an approach of differentiated restrictions by cantons ${ }^{3}$, as an intend to control the disease in zones where the contagions was high, and to allow certain level of economic activity in cantons with low number of cases. The number of cases by the end of July was 17.820, while the number of deaths was 150; figure 2 shows the evolution of COVID-19 cases in Costa Rica during the year.

FIGURE 01

\section{DAILY MOBILITY INDEX FROM GOOGLE MOBILITY REPORTS}

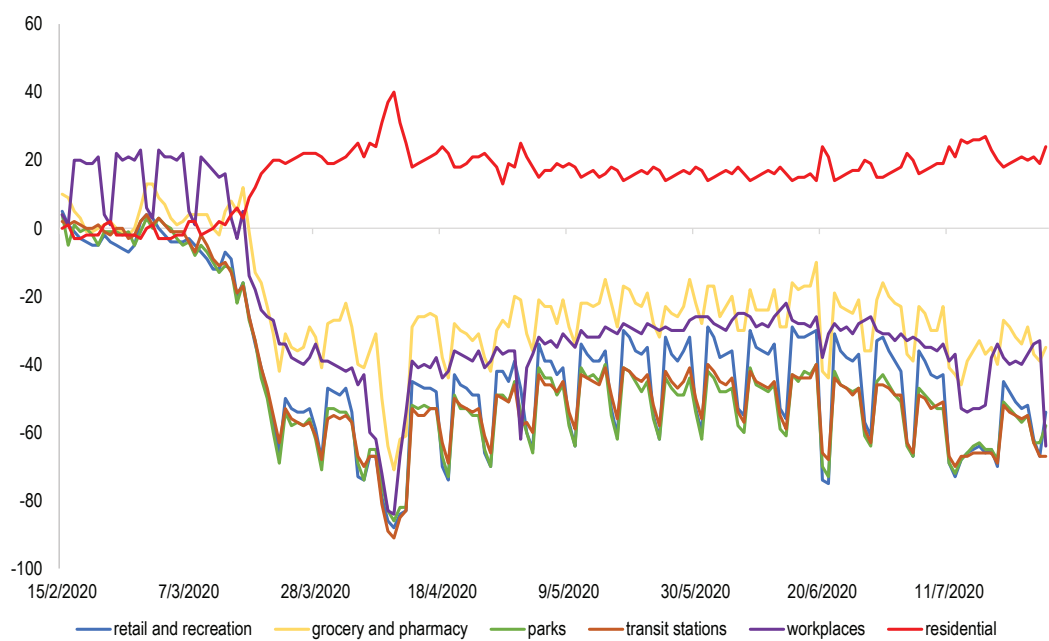

Note: Reference period corresponds to January 03rd to February 06th. Source: Google Mobility Reports

3 Costa Rica is organized in Provinces (7), each province is divided in cantons (82), and each canton is divided in districts (488). 
The Government has maintained the social distancing policies and restrictions on economic activity since March 2020, restaurants, retail stores, hotels, and services firms still faces total or partial lockdown depending on how strict are policies in their locations, airports reopened on August 2020 only for visitors from a limited list of countries. A detail of the economic impact during the first semester of 2020 and the policies implemented by the fiscal and monetary authorities can be found in (Central Bank of Costa Rica, 2020).

FIGURE 02.

DAILY NEW CASES OF COVID-19 CASES IN COSTA RICA.

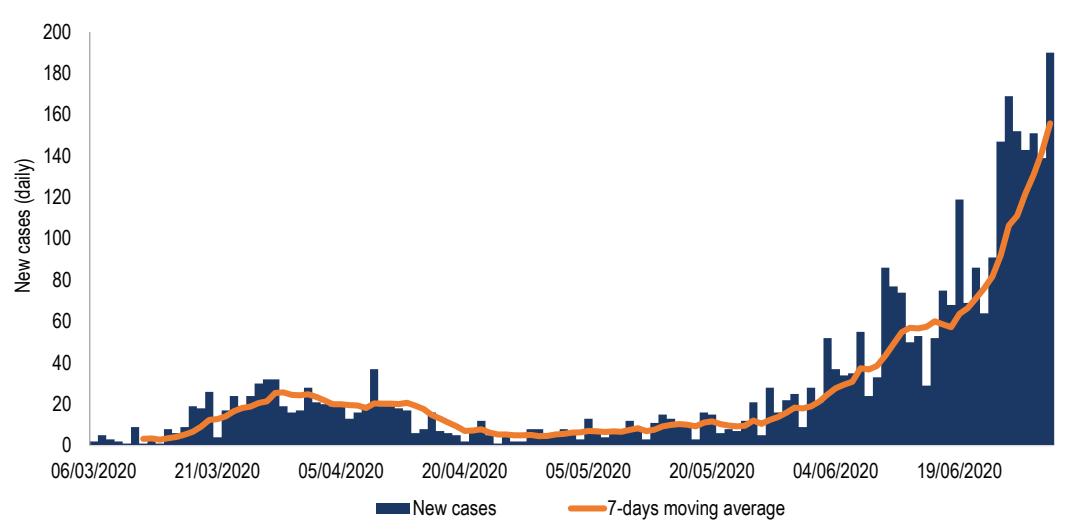

Note: Reference period corresponds to January 03rd to February 06th.

Source: Google Mobility Reports

The economic impact has been the deepest since the debt crisis in 1980, at May, the Central Bank of Costa Rica reported a contraction of the output of 7.5\%, while the unemployment rate reached 24.0\% in June (Figure 3). The Monetary Authority has announced that expects a contraction in the GDP of 5.0\% in 2020, and a slow recovery in 2021 (Central Bank of Costa Rica, 2020).

To mitigate the economic impact of the pandemic, the Government has implemented fiscal policies such as moratorium of value added taxes and income taxes, a temporary reduction in the social security contributions for employers, and subsidies from $\mathbb{L} 62.500 \mathbb{L} 125.000$ per worker (approximately 107 to 215 USD) for three months, covering 533.000 persons by the month of July. Regarding to monetary policy, the Central Bank implemented a reduction of the monetary policy rate to historic minimum levels, provision of liquidity by the purchase of government securities, provision of resources for credit to firms at low cost, easing on macro-prudential regulations to allow restructuring in credit contracts, among others (IMF, 2020a). 
FIGURE 03

\section{COSTA RICA: UNEMPLOYMENT RATE AND OUTPUT GROWTH}

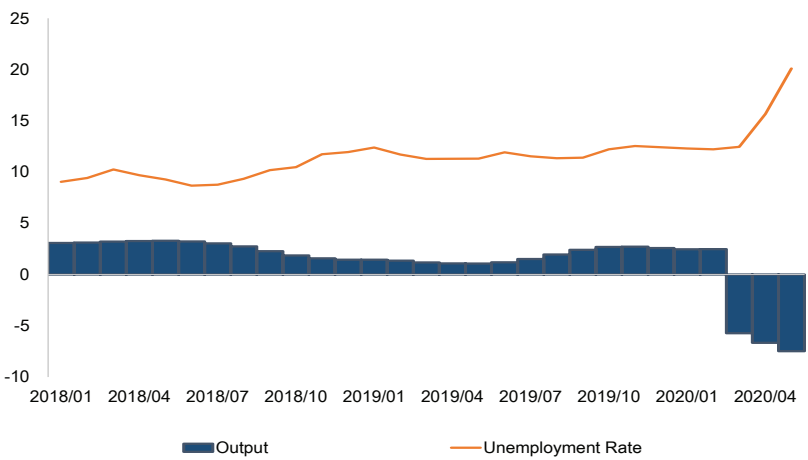

Notes: Output measured as the year over year variation of the Monthly Index of Economic Activity, published by the Central Bank of Costa Rica. Unemployment rate corresponds to the 3 months moving average unemployment rate, published by the National Institute of Statistics and Census.

Source: Central Bank of Costa Rica and National institute of Statistics and Census.

\section{DATA}

The data is obtained from " $w w w . b u s c o e m p l e o c r . c o m " 4$, a job advertisement webpage developed in 2010 by the Ministry of Labor and the Instituto Nacional de Aprendizaje ${ }^{5}$ (INA in Spanish). It has daily information from January 2010 to June 2020 of 253.667 vacancies for 15.282 firms (on average 1.488 firms per year) and 12.760 job applicants (1.160 applicants per year on average). Figure 4 present the weekly vacancy posts in buscoempleocr from week 1 to week 24 (from January to midJune). During the first 9 weeks the level and pattern of the vacancies posted is similar in both years, however, after week 10 in 2020 the number of vacancies shows a significant and persistent decline in 2020. Week 10 corresponds to the period when the lockdown began in Costa Rica, and it also coincides with the decline in mobility described in in Figure 1.

FIGURE 4

\section{NUMBER OF VACANCIES POSTED PER WEEK IN THE JOB ADVERTISEMENT WEBPAGE "BUSCOEMPLEOCR"}

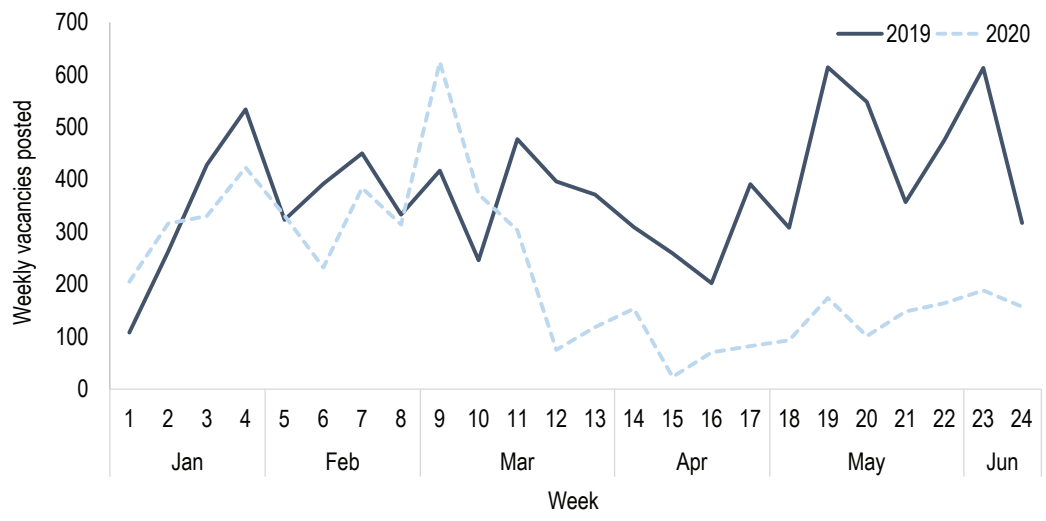

Source: Source: Author's estimates with data from buscoempleocr.

4 From September 2020, the webpage of buscoempleocr was replaced by the new address: www.ane.cr

5 The Instituto Nacional de Aprendizaje is a public institution in charge of technical education in the country. 
The data of vacancies includes: date, occupation, number of vacancies, location, education level required and the ISIC code of the firm who post the vacant, among others, while for the workers who post their CV looking for jobs, the dataset contains information about the gender, location, education level, date they post their $\mathrm{CV}$, and a maximum of five occupations selected by then as "occupations they desire to work for".

The coverage of the dataset is low in comparison with the total of firms and unemployed workers in the country. It also presents differences in the distribution by location, firms size and industries in comparison to other sources used as sampling frames for national surveys, which might indicate that the data is not strictly representative for the population of firms in Costa Rica. Appendix A explores these differences in detail.

Despite this, there are two arguments that support the use of data from buscoempleocr to estimate the effects of the pandemic in the labor market in Costa Rica. The first one, is that the data is consistent with the statistics of job vacancies from the Encuesta Nacional a Empresas (ENAE in Spanish), a quarterly survey developed by National Institute of Statistics and Census. For the period of study (January 2019 to June 2020), the data from both sources presents a common trend and a pearson correlation of 0.91 , statistically different from zero.

Figure 5 presents the data from both sources. On average, the level of vacancies from buscoempleocr is around 40\% of the weighted level estimated by the survey, but both series present a drop in the number of vacancies posted during 2019, an increase in the first quarter of 2020 and a decrease in the second quarter.

It is worth to say that even though the data obtained from ENAE comes from a representative sample, is not used as the main dataset in this paper for several: the survey response rate is low (around 58\%), the sample exclude firms with less than 10 workers, the frequency of the data is not optimal for the purpose of the study, and it is not possible to do inference at certain levels of disaggregation due to the sample size of aprox. 750 establishments reasons (Instituto Nacional de Estadística y Censos, 2018); but it is useful as a benchmark for our dataset ${ }^{6}$.

FIGURE 5

VACANCIES POSTED BY SOURCE

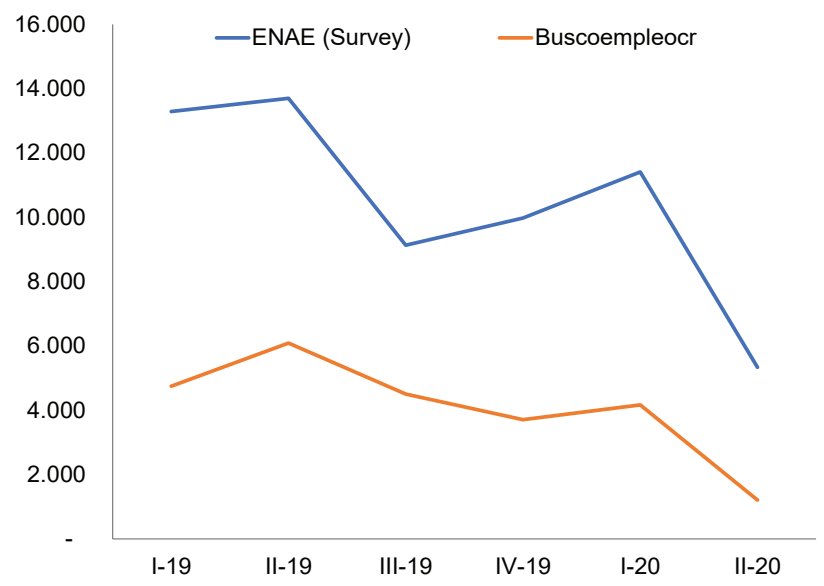

Source: Source: Author's estimates with data from buscoempleocr and National Institute of Statistics and Census

6 Additionally, methodological changes such as the variation of the questionnaire and adjustments in the sampling method in 2018 impede the comparison of the survey before and after that year. 
Second, the data of buscoempleocr exhibits a consistent trend with the output cycle and the outcomes of labor market, (i.e. the unemployment fluctuations). Theoretically, in expansions as the output increases, firms have incentives to post more job vacancies and hire new workers, as the expected value of these jobs are increasing, and consequently, the unemployment rate in the economy will fall. On the other hand, in recessions, firms will reduce their posts of vacancies, and might separate some workers as well, as a result, the unemployment rate will increase ${ }^{7}$.

In that sense, the data of buscoempleocr shows a procyclical behavior since 2010. Panel a of figure 6 presents the deviation of the logarithm of vacancies and output from its trend, obtained through the Hodrick-Prescott filter (Hodrick \& Prescott, 1997), it can be observed that when the output is above its trend the vacancies posted increases, and the opposite if the output is below its trend.

From panel b it can be seen that when the deviations of vacancies from its trend are positive, unemployment rate is decreasing, and conversely, if the deviations of the vacancies from its trend are negative, then the unemployment rate is above its trend.

FIGURE 6

GROSS DOMESTIC PRODUCT, VACANCIES AND UNEMPLOYMENT RATE: DEVIATIONS FROM ITS TREND IN LOGARITHMS.

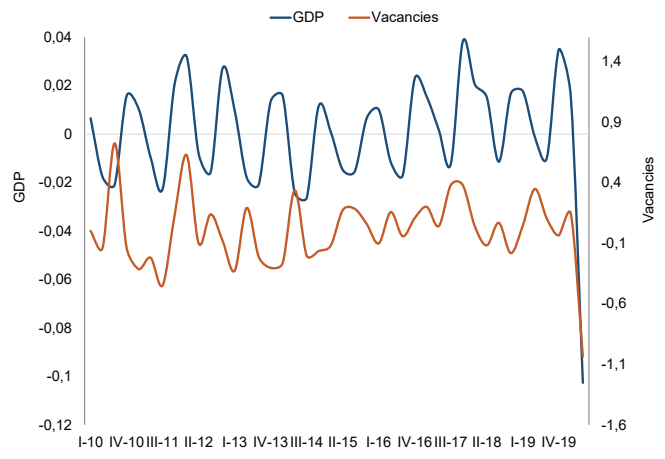

Panel b) Vacancies and Unemployment

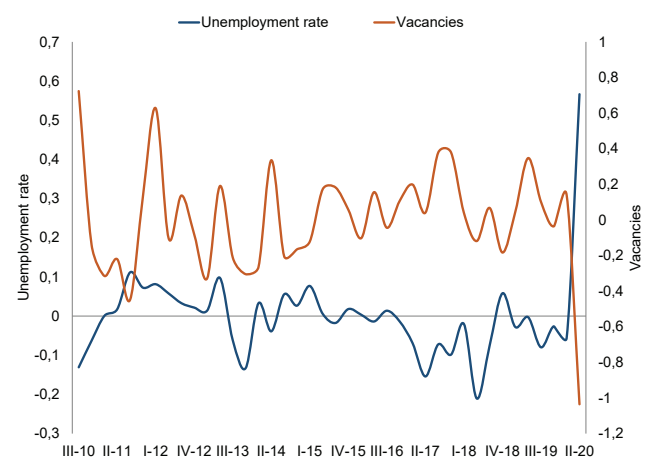

Notes: $\lambda$ value of 1600 .

Panel b presents data for III-10 to II-20 due to the availability of information for unemployment rate.

Source: Author's estimates with data from buscoempleocr and National Institute of Statistics and Census and Central Bank of Costa Rica

7 The relation between vacancies and unemployment in the search and matching models is defined as the Beveridge Curve. More details in (Pissarides, 2000) 
In sum, the dataset has some limitations due to the low number of vacancies reported in comparison with the size of the labor market, and the differences presented in its distribution in comparison to other sample frames. However, the data is consistent with the vacancies reported from a survey of national coverage, and also exhibits a trend consistent with the dynamics of the economy since 2010 and wit the outcome observed in the labor market in the same period. Thus, the dataset can be used to do inference for the labor market in Costa Rica, regarding an exogenous shock like the pandemic.

It is important to emphasize that there are no other datasets with information of vacancies and job seekers such as the one presented in this paper for Costa Rica. As mentioned previously, data of vacancies from the ENAE have some information about labor demand, but it is limited and present methodological issues that need to be conciliated and does not have data of job seekers. A mayor contribution of this research is the introduction of this new dataset of vacancies and job seekers, that can be used in the develop of new research about the functioning of the labor market in Costa Rica.

A second data source is Google Trends, which allows to download search intensity by topics. The data is provided as an index, where 100 represents the highest interest and 0 to the lowest. By downloading weekly data of topics like "jobs" is feasible to capture search intensity, following Shen (2020) and Fetzer et al. (2020). Figure 7 shows the search interest of users in Costa Rica for the topic "Jobs" in 2019 and 2020 per weeks. After the implementation of lockdown policies in week 10, the interest in jobs declined drastically among internet users, and it remains below the levels present in the previous year.

\section{FIGURE 7 \\ INDEX OF INTEREST FROM GOOGLE TRENDS FOR THE TOPIC “JOBS” IN COSTA RICA.}

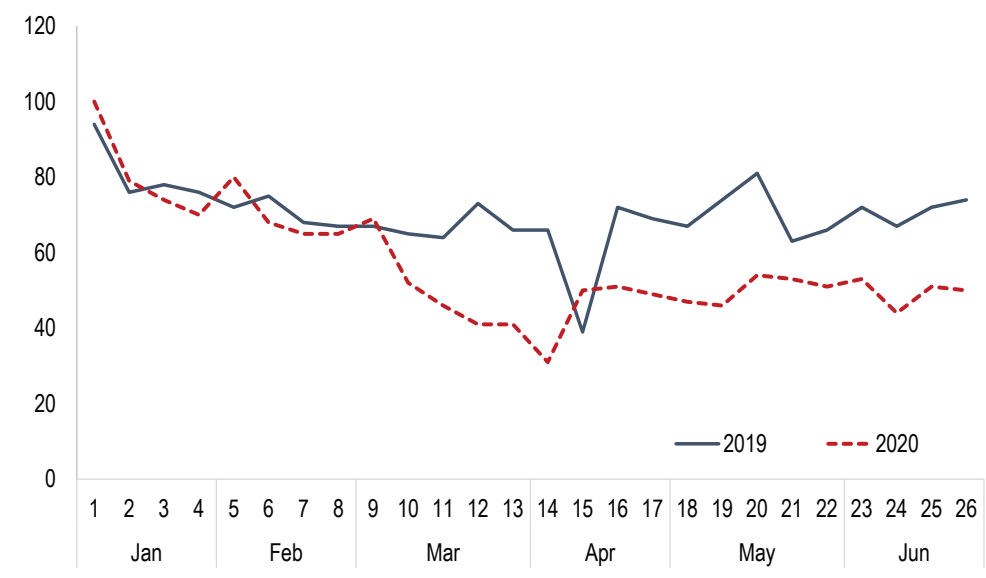

Note: "Index of Interest" of 100 indicates the highest interest, while 0 corresponds to the lowest interest. Source: Google Trends.

Other datasets used are the Continuous Employment Survey, developed by the Institute of Statistics and Census, which is the main source of labor market indicators. The Survey provides quarterly and monthly (from moving averages) indicators of the labor market, focused on the supply side. 


\section{METHODOLOGY}

The methodology suggested follows the empirical analysis presented in Hensvik, et al. (2021). The authors proposed the use of Differences in Differences to estimate the effect of the policies implemented to contain the pandemic on the labor demand. Similarly, in the present research it is proposed to estimate the equation:

$$
\ln \left(V_{w, y}\right)=\beta\left(\text { Treat }_{y} \times \text { Post }_{w}\right)+\lambda_{w}+\lambda_{y}+\epsilon_{w y}
$$

$V_{w, y}:$ Vacancy inflow at week w, year y.

Treat: Dummy variable, equal to 1 if year is 2020 $1-10)$

Post $_{w}$ : Dummy variable equal to 1 if vacancy is posted in week $11-24^{8}$ (0 if posted in week

$\lambda_{y}, \lambda_{w}:$ year and week fixed effects.

The beta coefficient is the parameter of interest, and it can be interpreted as the change in the vacancy inflow before and after the COVID-19 outbreak (week 10) in 2020 relative to the previous year.

This interpretation can be made under the assumption of "common trends", which means that, besides the COVID-19 sock in 2020, the trends in both years are the same, and there are no other exogenous factors that affects it. Note from Figures 4 and 7 that before week 10, the trend on the number of vacancies posted and Google searches of "Jobs" in Costa Rica is quite similar. A verification of this assumption is presented in the Appendix B.

Note that it can be expressed:

$$
\beta=\ln V_{20}-\ln V_{19}=\ln \left(V_{20} / V_{19}\right) ; \text { which is equal to: } \mathrm{e}^{\beta}=V_{20} / V_{19}
$$

Also,

$$
V_{20} / V_{19} \equiv 1+\left(\left(V_{20}-V_{19}\right) / V_{19}\right) \equiv \mathrm{e}^{\beta} \text {; implying that: } \mathrm{e}^{\beta}-1=\left(V_{20}-V_{19}\right) / V_{19}=\Delta V / V
$$

Which is especially useful in the case of large variations in the inflow of vacancies 9 .

The data allows to generate estimations by industry using the ISIC classification at one digit and by occupation disaggregating by one and two digits following the International Classification of Occupations (ISCO-08). Additionally, estimations will be presented by Province and cantons when is possible.

To estimate changes in search intensity, Hensvik et al. (2021) used the number of clicks on job adds as a main variable; this approach is also presented in Faberman and Kudlyak (2019). Since this variable is not available in the current dataset, other possibilities are explored. The following equation is suggested to estimate the effect of the pandemic on search intensity:

$$
\ln \left(S_{w, y}\right)=\left(\text { Treat }_{y} \times \text { Search }_{w}\right)+\lambda_{w}+\lambda_{y}+\epsilon_{w y}
$$

8 It corresponds to the second week of March to the second week of June, the latest data available.

9 In general, it can be shown that for small variations $\ln \left(1+\left(v t-v_{(t-1)}\right) / v_{(t-1)}\right) \approx\left(v_{t}-v_{(t-1)}\right) / v_{(t-1)}$ 
$S_{(w, y)} \quad$ : indicator of search intensity, at week $w$, year $y$.

Treat $_{\mathrm{y}}$ : Dummy variable, equal to 1 if year is 2020

Search $_{w}$ : Dummy variable equal to 1 if search is done in week $11-24$ (0 if posted in week 1-10) $\lambda_{y}, \lambda_{w} \quad$ : year and week fixed effects.

When a job seeker includes a CV in the webpage, he is asked to "select the occupations you would like to work for", it helps to find vacancies in the webpage, while allows the firms to filter candidates. The number of selected occupations can be used as an indicator of search intensity $\left(\mathrm{S}_{(w, y)}\right)$. Figure 8 shows the average number of desired occupations selected by job seekers in buscoempleocr. In general, the level of 2020 is below the observed data in 2019, however, the trend in both years bofere week 10 is very similar, and after the drop in 2020 is more pronounced.

FIGURE 8

\section{AVERAGE NUMBER OF OCCUPATIONS SELECTED BY JOB SEEKERS IN THE WEBPAGE BUSCOEMPLEOCR.}

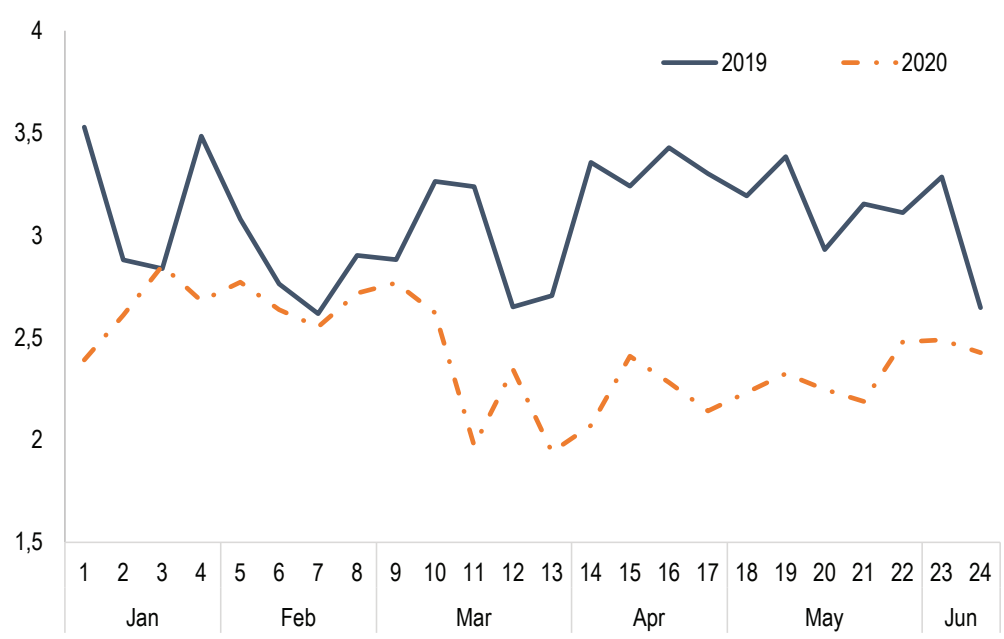

Source: Author's estimations with data from buscoempleocr.

Following Shen (2020), I additionally suggest the use of the data from Google Trends ${ }^{10}$ (Figure 7) for the word "jobs" in Costa Rica in the period 2019 - 2020 (weekly data) as another indicator of search intensity $\left(\mathrm{S}_{(w, y)}\right)$ in equation 2.

A third indicator used is the number of workers who uploads their CV into the webpage, this might reflect changes in the labor supply, or the "demand for jobs". A positive coefficient can be interpreted as an increase in the demand for jobs, and even though this result will not provide information about changes in search intensity, it results informative on how the workers reacts before and after the outbreak.

A fourth indicator evaluated is the "desired wage". The dataset contains data of the wages the workers expect to earn in their future jobs. Again, the wage that the workers expect to earn does not give information about their search intensity, but it does contribute to understand how the job seekers react on a context where the job finding rate might be lower.

10 The data of Google Trends has been used previously to estimate the increase in economic anxiety due to the COVID-19 pandemic in Fetzer et al. (2020). 
The estimation of equation 2 using the four indicators mentioned might give some evidence about how individuals adjust their search intensity, their participation in the labor market, and their reservation wages.

Before analysis of the results in the next section, some aspects should be mentioned. The first one, is that in the period of study, two major events affected the economy and the labor market outcomes: the pandemic and the social distancing policies. The surge of the pandemic might dissuade some workers to not participate in the market to protect themselves, while others might have been forced to left in case of contagion. On the other hand, the lockdown affected the economic activity, especially on those industries and occupations that cannot be done by work from home, which drops the output and employment.

The disaggregation of these effects is not feasible with the dataset available, therefore, the estimations presented in this paper should be interpreted as the result of both shocks on the labor demand and the search behavior of workers.

The second issue is the fact the pandemic started around two months before in Asia, Europe, and North America, therefore, the shock was not entirely unanticipated. If firms and workers knew about the risk of the pandemic in Costa Rica, they might have adjusted their expectations and their decisions regarding to search behavior and labor demand respectively.

If this is true, the estimations obtained from the identification strategy would be biased. However, even though the workers and firms might have known about the risks of a pandemic in the short term, there is no evidence of significant changes in their expectations about the economy in the first quarter of 2020.

Figure 9 shows some indicators of consumers and firm's expectations. Particularly, the Consumer Confidence Index exhibits an improvement in the first half of 2020 in comparison to the fourth quarter of 2019. Similarly, the Global Business Expectations Index indicates that firm's expectations didn't change in 2020 in comparison with the previous year.

Other indexes, such as the Economic Agent Confidence Index and the Business Confidence Index calculated by the Central Bank of Costa Rica and UCCAEP ${ }^{11}$ suggest a drop in expectations until the second quarter of 2020 , after the pandemic started.

These results allow to infer that economic agents did not adjust their expectations before the begin of the pandemic in Costa Rica, or at least not before the announcement of the first COVID19 positive cases and the implementation of the social distancing policies, which is consistent with assumption of common trends. Therefore, our estimations shouldn't be biased due variations in expectations.

11 Uccaep is the abbreviation in spanish for Unión Costarricense de Cámaras y Asociaciones del Sector Empresarial Privado, an organization that represents private companies from different industries in Costa Rica. 
FIGURE 9

INDICATORS OF FIRMS AND WORKERS EXPECTATIONS
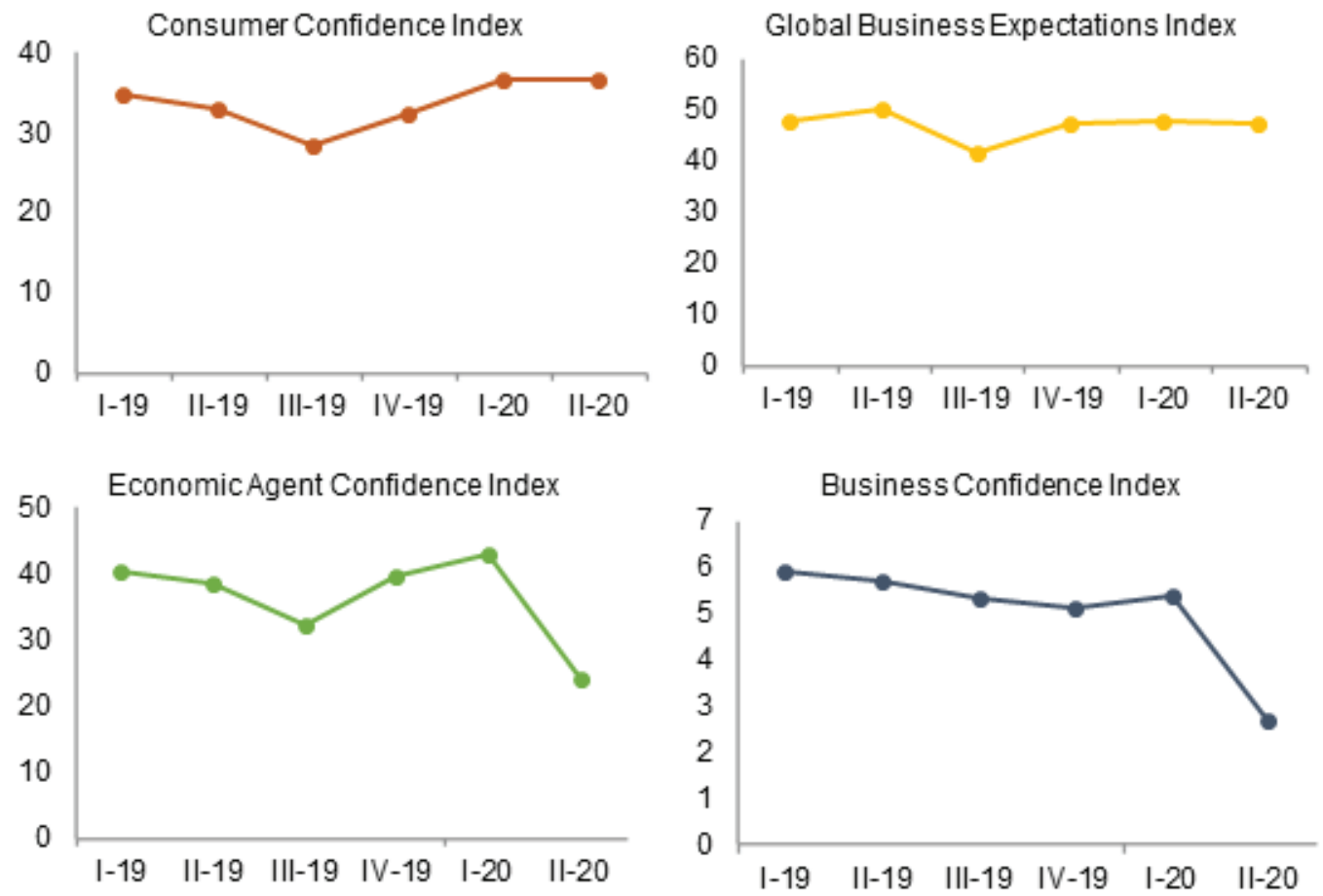

Source: Consumer Confidence Index: School of Statistics, Universidad de Costa Rica. Global Business Expectations Index: Instituto de Investigaciones en Ciencias Económicas, Universidad de Costa Rica. Economic Agent Confidence Index: Central Bank of Costa Rica. Business Confidence Index: UCCAEP. 


\section{RESULTS}

\section{Effect of COVID-19 on Labor Demand}

Difference in Difference estimates to compare the inflow of vacancies before and after week 10 in 2020 relative to 2019 reflects a reduction of $67.2 \%$ (Table 1), which implies that the group of firms that tends to post their vacancies in this webpage has dramatically reduced their labor demand. The estimated effect is consistent with the results presented in Hensvik, et al. (2021), Forsythe, et al. (2020) and Betcherman, et al. (2020).

TABLE 1

\section{ESTIMATED EFFECT ON THE INFLOW OF VACANCIES BEFORE AND AFTER WEEK 10 IN} 2020, RELATIVE TO THE PREVIOUS YEAR.

\begin{tabular}{lcccc}
\hline & Coef. & P Value & \multicolumn{2}{c}{$95 \%$ Confidence Interval } \\
\hline Beta & $-1.116^{* * * *}$ & 0.000 & -1.543 & -0.688 \\
& $(0.206)$ & & & \\
$\Delta$ inflow of vacancies (\%) & -67.2 & & -78.6 & -49.8 \\
& & & & \\
Week Fixed Effects & Yes & & & \\
Year Fixed Effects & Yes & & F Test & 63.640 \\
Number of observations & 48 & & P Value & 0.000 \\
R Squared & 0.844 & & & \\
\hline
\end{tabular}

Robust standard errors in parentheses

$* * * \mathrm{p}<0.01, * * \mathrm{p}<0.05, * \mathrm{p}<0.1$

Notes: Model estimated by Differences in Differences, following the specification presented in equation 1 . The coefficient estimated is interpreted as a reduction of $67 \%$ in the inflow of vacancies before and after week 10 , relative to the same period in previous year. It is estimated as $e^{(-1.12)}-1=0.672$, or $67.2 \%$.

Source: Author's estimates with data from buscoempleocr.

This result, while large, is not surprising considering that the unemployment rate in Costa Rica increased from $12.4 \%$ by the end of 2019 to $24.0 \%$ at the second quarter of 2020 , and the furlough requests received by the Ministry of Labor are near a $10 \%$ of the employed workers (Ministerio de Trabajo y Seguridad Social, 2020).

\section{Effect on labor demand by industries.}

The Difference in Difference estimates reflect that accommodation and food service activities is the most affected industry, with a drop in the post of vacancies of $-86.0 \%$, followed by Education (-82.6\%) and Administrative and Support Service Activities (-80.5\%). Table 2 presents the coefficients by industry. The estimated effect is negative in most of the industries, except for arts, entertainment and recreation, water supply, mining and quarrying and real estate activities, which registered a modest but not statistically significant increase.

12 As mentioned previously in the methodological section, the reduction in the inflow of vacancies can be calculated from the Differences in Differences coefficient as follows: $\mathrm{e}^{\beta}-1=\Delta V / V$. This is how the effects will be reported in this paper.. 
In the case of hotels and restaurants industry, the lockdown and social distancing policies had a significant impact. The Central Bank of Costa Rica stated that the occupation index for hotels has drop from 93\% in January to a minimum level of 10\% in May and a current level of 34\% in July (Central Bank of Costa Rica, 2020). Therefore, the estimated drop in labor demand is an expected result.

Similarly, the result in Education is consistent with the suspension of in person classes since March of 2020. Alternatively, the Ministry of Education has adapted the programs to online lessons and some new alternative programs to keep students active while the lockdown continues. On the other hand, the Government has asked for extraordinary budget cuts to their Ministries, included the Ministry of Education due to the high Government fiscal deficit in 2019 (7\% of GDP). This fact affects new hiring in public schools, while private schools might had experienced a slowdown in their demand.

TABLE 2

ESTIMATED EFFECT ON THE INFLOW OF VACANCIES BEFORE AND AFTER WEEK 10 IN 2020, RELATIVE TO THE PREVIOUS YEAR BY INDUSTRY (ISIC 1 DIGIT).

\begin{tabular}{|c|c|c|c|c|}
\hline ISIC - 1 digit & Beta & $\begin{array}{l}\text { Robust Std. } \\
\text { Error }\end{array}$ & $\begin{array}{l}\Delta \text { inflow of } \\
\text { vacancies } \\
(\%)\end{array}$ & R-Squared \\
\hline Accommodation and food service activities & $-1.963^{* * *}$ & $(0.431)$ & -86.0 & 0.781 \\
\hline Education & $-1.748^{* *}$ & $(0.626)$ & -82.6 & 0.692 \\
\hline Administrative and support service activities & $-1.634^{* * *}$ & $(0.507)$ & -80.5 & 0.682 \\
\hline $\begin{array}{l}\text { Public administration and defence; compulsory } \\
\text { social security }\end{array}$ & $-1.598 * * *$ & $(0.565)$ & -79.8 & 0.623 \\
\hline Human health and social work activities & $-1.422^{* *}$ & $(0.525)$ & -75.9 & 0.701 \\
\hline Information and communication & $-1.279^{*}$ & $(0.646)$ & -72.2 & 0.622 \\
\hline Transportation and storage & $-1.195^{*}$ & $(0.608)$ & -69.7 & 0.609 \\
\hline Total & $-1.107 * * *$ & $(0.204)$ & -66.9 & 0.844 \\
\hline Financial and insurance activities & $-0.966 * *$ & $(0.448)$ & -61.9 & 0.698 \\
\hline $\begin{array}{l}\text { Wholesale and retail trade; repair of motor vehicles } \\
\text { and motorcycles }\end{array}$ & $-0.951^{* *}$ & $(0.375)$ & -61.4 & 0.675 \\
\hline Electricity, gas, steam and air conditioning supply & $-0.906^{* *}$ & $(0.364)$ & -59.6 & 0.603 \\
\hline Other service activities & -0.721 & $(0.435)$ & -51.4 & 0.675 \\
\hline Agriculture, forestry and fishing & -0.639 & $(0.435)$ & -47.2 & 0.507 \\
\hline Construction & -0.415 & $(0.411)$ & -34.0 & 0.556 \\
\hline Manufacturing, Mining and Quarrying & -0.241 & $(0.365)$ & -21.4 & 0.654 \\
\hline Arts, entertainment and recreation & -0.105 & $(0.223)$ & -10.0 & 0.752 \\
\hline Professional, scientific and technical activities & -0.066 & $(0.616)$ & -6.4 & 0.728 \\
\hline $\begin{array}{l}\text { Water supply; sewerage, waste management and } \\
\text { remediation activities }\end{array}$ & 0.414 & $(0.361)$ & 51.3 & 0.569 \\
\hline Real estate activities & 0.567 & $(0.350)$ & 76.3 & 0.492 \\
\hline
\end{tabular}

$* * * p<0.01, * * p<0.05, * p<0.1$

Notes: Model estimated by Differences in Differences, following the specification presented in equation 1 . The coefficient estimated is interpreted as a reduction of $67 \%$ in the inflow of vacancies before and after week 10, relative to the same period in previous year. It is estimated as $\mathrm{e}^{\wedge}(-1.12)-1=0.672$, or $67.2 \%$.

Source: Author's estimates with data from buscoempleocr. 
The drop in the demand of workers from administrative and support service industry reflects the fact that the current pandemic not only affects industries where social contact is intrinsic to their activities, such as tourism, hotels, restaurants and education, it also generates a disruption in the supply chain of firms, causing a contraction in the demand of administrative and support services, which has an effect in the hiring decisions of the firms.

The same argument is valid to explain the contraction in transportation and storage (-69.7\%) and information and communication $(-72.2 \%)$, both industries that produce inputs services to the rest of the economy.

In general, the reduction in labor demand within industries might be explained as composed the effect of a restricted aggregate demand due to lower disposable income, a contraction in international trade, higher costs of production due to a disruption in the supply chain as a consequence of the pandemic and the policies implemented.

\section{Effect on labor demand by occupation.}

By occupation at one digit of International Standard Classification of Occupations (ISCO), it is founded that services and sales workers are the most affected (-91.1\%), followed by the elementary occupations (-72.2\%) and Clerical and Support Workers (-70.9\%), as shown in Table 3.

The results at two digits of ISCO are not robust in some cases, however these are included to illustrate in detail the effects by occupation. The greatest drop in the inflow of vacancies posted are in Personal Services Workers (-87.7\%), Sales Workers (-79.8\%), Food Preparation Assistants (-79.0\%), Electrical and Electronic Trades Workers (-74.6\%) and Protective Services Workers (-73.8\%), as presented in Appendix C.

On the other hand, the less affected occupations were Other Technicians, Administrative and Commercial Managers, Handicraft and Printing Workers, Assemblers and Stationary Plant and Machine Operators. These occupations reported an increase in the number of vacancies posted, but not statistically significant (Appendix C).

TABLE 3

ESTIMATED EFFECT ON THE INFLOW OF VACANCIES BEFORE AND AFTER WEEK 10 IN 2020, RELATIVE TO THE PREVIOUS YEAR BY TYPE OF OCCUPATIONS (ISCO 1 DIGIT).

\begin{tabular}{|c|c|c|c|c|}
\hline ISCO - 1 digit & Beta & $\begin{array}{c}\text { Robust Std. } \\
\text { Error }\end{array}$ & $\begin{array}{c}\Delta \text { inflow of } \\
\text { vacancies }(\%)\end{array}$ & R-Squared \\
\hline Service and sales workers & $-2.424^{* * *}$ & $(0.339)$ & -91.1 & 0.848 \\
\hline Elementary occupations & $-1.281 * *$ & $(0.465)$ & -72.2 & 0.638 \\
\hline Clerical support workers & $-1.233^{* *}$ & $(0.534)$ & -70.9 & 0.751 \\
\hline Total & $-1.107 * * *$ & $(0.204)$ & -66.9 & 0.844 \\
\hline Professionals & $-0.978 * *$ & $(0.416)$ & -62.4 & 0.800 \\
\hline Plant and machine operators and assemblers & -0.894 & $(0.531)$ & -59.1 & 0.539 \\
\hline Managers & -0.886 & $(0.626)$ & -58.8 & 0.626 \\
\hline Craft and related trades workers & $-0.717 * *$ & $(0.337)$ & -51.2 & 0.615 \\
\hline Technicians and associate professionals & $-0.698 * *$ & $(0.297)$ & -50.2 & 0.641 \\
\hline Skilled agricultural, forestry and fischery & -0.342 & $(0.208)$ & -29.0 & 0.585 \\
\hline
\end{tabular}

Notes: Models estimated by Differences in Differences, following the specification presented in equation 1. Each row in the table corresponds to a model estimated by each type of occupations at ISCO 1 digit, including week and year fixed effects. Source: Author's estimates with data from buscoempleocr. 
The results suggest that the highest contraction in labor demand is focused on occupations that demand low skilled workers and that often pays the lowest wages. Therefore, there is a possibility that the current pandemic is not only reducing the job opportunities for workers, but also is reducing it more for those who even in "normal circumstances" tend to match jobs with low wages. This is consistent with the results presented in Dingel and Neiman (2020), Hensvik, et al. (2020) and Yasenov (2020).

\section{Effect on labor demand by location}

It is possible to compute differences in differences estimates by provinces to capture the drop in labor demand by the firms who post vacancies in different regions. The data of vacancies by location allows to determine where some types of jobs are more demanded and where the labor demand is concentrated. Figure 10 presents the average composition of the vacancies posted in buscoempleocr from 2015 to 2019. As expected, most of the vacancies are concentrated in the cantons located in the Central Region of the country and in the capitols of the provinces, which contrasts with the cantons in the Central Pacific Region, where the proportion of vacancies posted is lower ${ }^{13}$.

\section{FIGURE 10 \\ COMPOSITION OF VACANCIES POSTED IN BUSCOEMPLEOCR BY CANTON. AVERAGE COMPOSITION IN $2015-2019$.}

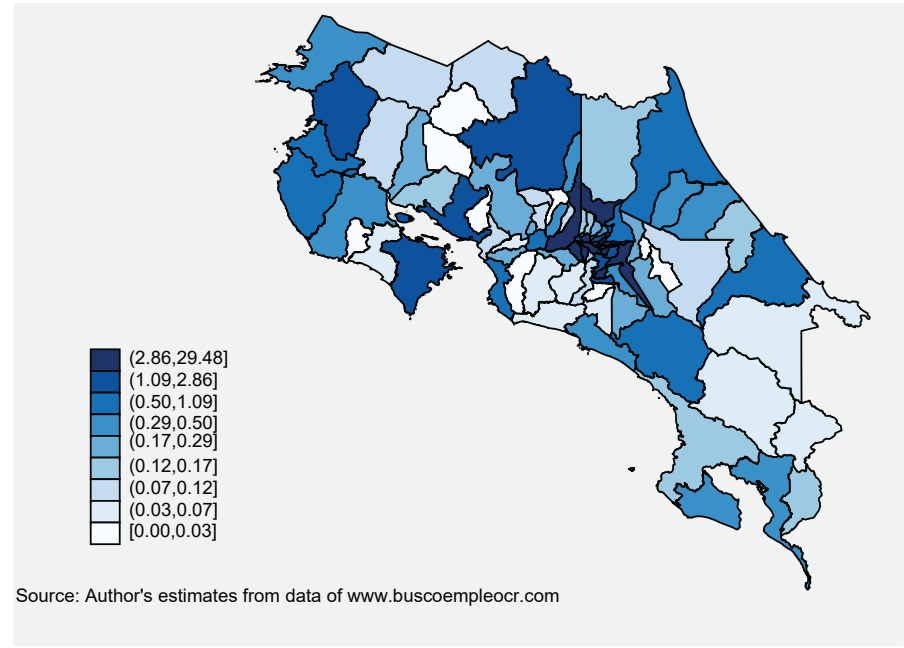

Appendix $\mathrm{C}$ shows the average composition of the vacancies posted on buscoempleocr by cantons in Costa Rica from 2015 to 2019 by industry. It can be checked, for example, how demand of agricultural jobs are concentrated in the cantons at the north of the country, where most of these activities are developed, similarly the vacancies of accommodation and food service activities are concentrated in cantons near the most visited beaches in Guanacaste, in the north region especially in San Carlos, which annually receives many visitors due to attractions such as volcanoes, hot waters and tourism of adventure, and the region of the South Pacific coast also known by their beaches and national parks.

13 From author's knowledge, this is the first paper that presents data of the composition of the labor demand by locations, but the reader must take into account the limitations of the data used, and interpret the results as a first exploratory approach to determine some characteristics of the labor demand in Costa Rica, since there are no other sources available with this information. 
Estimates by province shows that Guanacaste and Limon are the ones that present the deepest drop in the inflow of vacancies, with $-87.0 \%$ and $-85.6 \%$ respectively (Figure 11). Both are provinces with coasts, where the activities related to tourism play a major role in economic activity. These two provinces are followed by Heredia (-74.7\%) and San José (-70.4\%), the last one is the capital of the country and concentrates most of the firms and employment.

The least affected provinces are Alajuela (-67.6\%), Puntarenas (-59.5\%) and Cartago (-21.0\%). In general, it is estimated a drop in the inflow of vacancies posted by firms in every province, and the size is considerable. Table 4 presents the detail of these estimations.

TABLE 4

ESTIMATED EFFECT ON THE INFLOW OF VACANCIES BEFORE AND AFTER WEEK 10 IN 2020, RELATIVE TO THE PREVIOUS YEAR BY PROVINCES.

\begin{tabular}{|c|c|c|c|c|c|c|c|}
\hline & (1) & (2) & (3) & (4) & (5) & (6) & (7) \\
\hline & Alajuela & Cartago & Guancaste & Heredia & Limón & Puntarenas & San José \\
\hline \multirow[t]{2}{*}{ Beta } & $-1.126^{* * *}$ & -0.236 & $-2.043 * * *$ & $-1.376^{* * * *}$ & $-1.938 * * *$ & $-0.903 * *$ & $-1.217 * * *$ \\
\hline & $(0.439)$ & $(0.339)$ & $(0.548)$ & $(0.375)$ & $(0.503)$ & $(0.430)$ & $(0.296)$ \\
\hline$\Delta$ inflow of vacancies $(\%)$ & -67.6 & -21.0 & -87.0 & -74.7 & -85.6 & -59.5 & -70.4 \\
\hline Observations & 48 & 48 & 48 & 48 & 48 & 48 & 48 \\
\hline R-squared & 0.628 & 0.656 & 0.677 & 0.799 & 0.609 & 0.672 & 0.821 \\
\hline
\end{tabular}

Robust standard errors in parentheses.

$* * * \mathrm{p}<0.01, * * \mathrm{p}<0.05, * \mathrm{p}<0.1$

Notes: Models estimated by Differences in Differences, following the specification presented in equation 1. Each column in the table corresponds to a model estimated by each Province, including week and year fixed effects.

Source: Author's estimates with data from buscoempleocr.

Appendix $\mathrm{E}^{14}$ presents the estimated differences in differences regressions for cantons that had at least $1 \%$ of the total of vacancies from week 1 to week 24 in 2019. The 20 cantons selected accumulates the $89.5 \%$ of the vacancies for the period mentioned and $86.5 \%$ for the same period in 2020, as presented in Table E1.

The results suggest that the cantons whit the highest reduction in the inflow of vacancies were Montes de Oca (-75.2\%), Liberia (-74.1\%), Alajuela (-72.4\%), Belen (-69.6\%) and Escazú (-67.5\%). The cantons of Montes de Oca, Belén and Escazú are cities with high industry concentration, while Alajuela, and Liberia corresponds to the capitals of the provinces of Alajuela, Guanacaste respectively. Therefore, the results suggest a higher reduction on the labor demand in major cities (Table E2 from Appendix E.).

14 The main purpose of include estimates by cantons is to contribute to the discussion of the heterogeneous effects of the pandemic on the labor market. These results are estimated with the best data available at this level of disaggregation, however, since the number of cases is low, should be interpreted carefully, considering also that labor markets at cantons level might not be segmented. 


\section{Effect of COVID-19 on search behavior}

This section presents some estimations that might contribute to understand how the job seekers reacted to the pandemic and the policies implemented to contain the spread of the virus. As previously introduced in the data section, the number of "desired occupations" selected by the job seekers is included in the dataset. In weeks 1 to 9 in 2019 and 2020, it can be observed a similar pattern on the number of desired occupations selected by applicants. After week 10, when the lockdown policies started, the number of selected occupations drops dramatically in 2020 compared to 2019 (Figure 6).

An hypothesis to explain this phenomenon is that if job seekers consider that it will be more difficult to find jobs in particular occupations, they will reduce their "effort" of search by not selecting those, or selecting just occupations that they consider more likely to be matched. A second possibility is that the job seekers are redirecting their search only through occupations with lower risk of contagion, as proposed by Basso, et al. (2020), in that case, certain types of occupations could be "excluded" by applicants. Both explanations are reflecting changes in the search intensity of job seekers.

Changes in search intensity are an expected result under a recessionary period. A theoretical analysis of the pro-cyclicality of search intensity is presented in Elsby, et al. (2015), and empirical evidence has been documented in DeLoach and Kurt (2013), Gomme and Lkhagvasuren (2015), Hensvik, et al. (2021), Krueger and Mueller (2010), Krueger and Mueller (2011). In general, workers might reduce their search intensity if they consider that job finding rate is reduced, or if the mismatch in labor market has increased due to exogenous reasons.

For Costa Rica, it is estimated that the average number of desired occupations selected by job seekers is reduced in $40 \%$ before and after week 10 in 2020 relative to 2019 . This result suggests that job seekers in buscoempleocr reacted quickly to adapt their job search in the context of a pandemic (Table 5, column 1).

TABLE 5

DIFFERENCES IN DIFFERENCES ESTIMATES OF THE RESPONSE OF SELECTED INDICATORS OF SEARCH BEHAVIOR BEFORE AND AFTER WEEK 10 OF 2020, RELATIVE TO THE SAME PERIOD IN 2019.

\begin{tabular}{|c|c|c|c|c|}
\hline & $\begin{array}{c}\text { (1) } \\
\text { \# of Desired } \\
\text { occupations }\end{array}$ & $\begin{array}{l}\text { Log of wage } \\
\text { desired }\end{array}$ & $\begin{array}{l}\text { (3) } \\
\text { \# of applicants in } \\
\text { buscoempleocr }\end{array}$ & $\begin{array}{l}\text { (4) } \\
\text { Google Index of } \\
\text { Interest for "Jobs }\end{array}$ \\
\hline Beta & $\begin{array}{c}-0.515^{* * * *} \\
(0.151)\end{array}$ & $\begin{array}{l}-0.106 \\
(0.082)\end{array}$ & $\begin{array}{c}0.898^{* * * *} \\
(0.204)\end{array}$ & $\begin{array}{c}-0.338 * * * \\
(0.061)\end{array}$ \\
\hline Estimated effect (\%) & -40.2 & -10.1 & 145.5 & -28.7 \\
\hline Observations & 48 & 48 & 48 & 48 \\
\hline R-squared & 0.846 & 0.497 & 0.918 & 0.869 \\
\hline
\end{tabular}

Robust standard errors in parentheses.

$* * * \mathrm{p}<0.01, * * \mathrm{p}<0.05, * \mathrm{p}<0.1$

Notes: Models estimated by Differences in Differences, following the specification presented in equation 2. Each column presents a model estimated where the dependent variable corresponds to each indicator of search behavior. In column 1 , model in equation 2 is estimated for the number of desired occupations selected by job seekers in the webpage buscoempleocr; column 2 presents the estimated regression for the logarithm of the desired wage reported by the job seekers in buscoempleocr; column 3 reports the model for the logarithm of the Index of interest for web searches of the topic "Jobs" estimated by Google. Finally, column 4 reports the result of the model estimated for the number of applicants in buscoempleocr in logs.

Source: Author's estimates with data from buscoempleocr. 
During a recession, where unemployment increases significantly and the number of vacancies posted decreases, job seekers must compete among more workers to find a job. Under such context, it is likely that some of them react by reducing their reservation wage to match a job easily. The webpage of buscoempleocr collects data of the "desired wage" of the job seekers, while this is not exactly a reservation wage, it gives information about the wage a job seeker expects to earn, and that is consistent with her skills and the expected economic performance. Therefore, if workers consider that firms will not pay a particular wage for their services, because there are many competitors, or because the economy is in recession, they might adjust their desired wage to ease the match with a firm. It is founded that before and after week 10 in 2019 relative to 2020 the job seekers reduced their desired wage in $10 \%$, however, this is not statistically significant (Table 5 column 2 ).

Additionally, the effect in the log of the number of job seekers in buscoempleocr before and after the COVID-19 outbreak was estimated. On average, there is an increase of $145 \%$ in the number of workers looking for jobs after week 10, which is consistent with i) the increase in number of unemployed workers, ii) the social mobility restrictions that limits in person job search and iii) changes in search behavior of workers through a more intensive use of online platforms that might had been reinforced by the pandemic (Table 5, column 3).

Table 6 presents the levels and distribution of job seekers in buscoempleocr during week 1 to 24 in 2019 and 2020. It can be noticed that i) There is a significant increase in the number of job seekers in 2020, ii) there are not significant differences by province of origin of the worker, but iii) there are differences by groups of age, gender, and education level. In 2020 the proportion of job seekers between 15 to 24 years increased in comparison to 2019, while by education level, it can be observed an increase in the share of workers with insufficient secondary education. It might be possible that the pandemic has pushed young workers to drop their studies, as suggested by Chatterji and Li (2021) and Musaddiq, et al. (2021) for United States and Lichand, et al. (2021) in Brazil; possibly some of them might have entered to the labor force. To check the veracity of this hypothesis is not trivial, and is beyond the purpouse of this paper, but it is suggested as research topic for a future agenda.

In general, the results suggests that, i) there is an increase in the number of unemployed workers and the number of job seekers in the labor market, but ii) it seems like workers are searching less intensively, considering the decrease in the desired occupations selected and the adjusts in their expected wages.

As an additional exercise, the data from Google Trends on the interest for the word "jobs" in Costa Rica is used to approximate the intensity of search by job seekers before and after the pandemic. As previously detailed in Figure 5, the interest in jobs before week 10 was very similar in 2019 and 2020, but after that the interest drop and has remained below the levels observed in 2019. Differences in Differences estimates confirms a reduction of $28.7 \%$ in the interest on jobs by internet users in Costa Rica during the lockdown (Table 5, column 4). 
TABLE 6

DISTRIBUTION OF JOB SEEKERS IN BUSCOEMPLEOCR BY GROUPS OF AGE, GENDER, EDUCATION LEVEL AND PROVINCE IN WEEKS 1 TO 24 IN 2019 AND 2020

\begin{tabular}{|c|c|c|c|c|}
\hline & \multicolumn{2}{|c|}{ Levels } & \multicolumn{2}{|c|}{ Composition } \\
\hline & 2019 & 2020 & 2019 & 2020 \\
\hline \multicolumn{5}{|l|}{ Groups of age } \\
\hline 15 to 24 & 332 & 2,997 & 37.4 & 53.2 \\
\hline 25 to 34 & 323 & 1,608 & 36.4 & 28.5 \\
\hline 35 to 44 & 132 & 601 & 14.9 & 10.7 \\
\hline 45 to 59 & 94 & 406 & 10.6 & 7.2 \\
\hline 60 or more & 7 & 24 & 0.8 & 0.4 \\
\hline Unknown & 0 & 0 & 0.0 & 0.0 \\
\hline Total & 888 & 5,636 & 100.0 & 100.0 \\
\hline \multicolumn{5}{|l|}{ Gender } \\
\hline Female & 412 & 3,023 & 46.4 & 53.6 \\
\hline Male & 476 & 2,613 & 53.6 & 46.4 \\
\hline Total & 888 & 5,636 & 100.0 & 100.0 \\
\hline \multicolumn{5}{|l|}{ Education Level } \\
\hline $\begin{array}{l}\text { Primary education } \\
\text { (insufficient) }\end{array}$ & 4 & 51 & 0.5 & 0.9 \\
\hline Primary education & 27 & 275 & 3.0 & 4.9 \\
\hline $\begin{array}{l}\text { Secondary education } \\
\text { (insufficient) }\end{array}$ & 112 & 1,232 & 12.6 & 21.9 \\
\hline Secondary education & 310 & 2,233 & 34.9 & 39.6 \\
\hline $\begin{array}{l}\text { College education } \\
\text { (insufficient) }\end{array}$ & 125 & 685 & 14.1 & 12.2 \\
\hline College education & 309 & 1,160 & 34.8 & 20.6 \\
\hline Unknown & 1 & 0 & 0.1 & 0.0 \\
\hline Total & 888 & 5,636 & 100.0 & 100.0 \\
\hline \multicolumn{5}{|l|}{ Province } \\
\hline Alajuela & 73 & 728 & 8.2 & 12.9 \\
\hline Cartago & 136 & 883 & 15.3 & 15.7 \\
\hline Guanacaste & 36 & 244 & 4.1 & 4.3 \\
\hline Heredia & 91 & 682 & 10.2 & 12.1 \\
\hline Limón & 17 & 272 & 1.9 & 4.8 \\
\hline Puntarenas & 50 & 339 & 5.6 & 6.0 \\
\hline San José & 485 & 2,488 & 54.6 & 44.1 \\
\hline Total & 888 & 5,636 & 100.0 & 100.0 \\
\hline
\end{tabular}

Source: Author's estimates with data from buscoempleocr. 


\section{CONCLUDING REMARKS}

This paper presented evidence on how firms and workers in Costa Rica responded to the pandemic and the policies implemented to contain the spread of COVID-19. The data available of vacancies has some limitations, however, it is consistent with other sources of vacancies, it presents a procyclical behavior and a negative relationship with unemployment, as described in the search and matching models (Pissarides, 2000). Therefore, it possible to infer that the data of buscoempleocr reflects the dynamics of the labor market in Costa Rica consistently.

The number of vacancies posted from on the online webpage buscoempleocr reported a drastic reduction since the pandemic started and policies established by the Government were implemented in week 10 (March) of 2020. The drop in labor demand has being persistent during the period studied and presents a heterogeneous response among industries. The firms of accommodation and food service presented the highest contraction in labor demand, a consistent result with the policies implemented, such as the lockdown of the economy for foreign visitors, local travel restrictions and closure of non-essential business.

Education has reported a dramatically reduction in their demand of workers. While the Government has opted to suspend in person classes and substitute them by online activities, it has also postponed the hiring of new teachers due to budget constraints, and similarly it is expected that private schools might postponed their vacancy posting. Administrative support and service activities is the third industry with the highest drop in labor demand, this might be reflecting how social distancing policies have a significant impact on the input chains among firms.

By occupation, it was found that the highest decline in vacancy posts is on jobs for personal service workers, sales workers, and some elementary occupations. These results are consistent with the empirical research discussed in the literature review section and adds new evidence on how the pandemic has affected more severely the low skilled workers and with vulnerability conditions in Latin American country. By its nature, most of the occupations who demands low skilled workers are not feasible to do remotely, which means more risk of contagion, while the occupations that demands high skilled workers has better wages on average and are more feasible to do adapt for home working. In that sense, the current recession has introduced a new type of inequality in the labor market.

The data from buscoempleocr allows to track the vacancies from their provinces to analyze where the labor demand is concentrated. Appendix D presents maps of the concentration of labor demand by cantons and industries, the use of geographical data can contribute to a deeper understanding of the labor markets are structured and to evaluate possible regional mismatches and vacancy concentrations in particular regions. The analysis by location adds a new dimension in the study of the dynamics of the labor demand in the context of COVID-19; something that has not being developed in other papers for Costa Rica, probably due to the lack of information.

The results by location are consistent with the estimations by industry and occupation. The most affected regions in Costa Rica are those where the activities like tourism are important. Particularly, the most affected provinces are Guanacaste and Limón, both with internationally recognized by their natural attractions and their touristic industry. The other regions that are severely affected are the cantons that are center of provinces, where most of the firms are concentrated.

This is a significant contribution for the case of Costa Rica, since from the author's knowledge, there are no previous studies of the labor demand that involves a regional analysis. The results obtained are consistent with what is "common knowledge" about the economic activities by region, nevertheless, in future research this should be confirmed, due to the limitations of the dataset, detailed in Appendix A. 
This paper presented evidence of how the individuals reacted by changing their search behavior in the market. When the lockdown policies started after week 10 in Costa Rica, the number of job applicants increased significantly in buscoempleocr, however, the number of selected "desired occupations" selected by job seekers declined, this might be reflecting a reduction in the search intensity consistent with the literature of procyclicality of search intensity. Another possibility is that job seekers reduced the number of occupations to avoid those where they believe the risk of contagion in higher. To confirm this hypothesis is beyond the present research, but it is suggested to be considered for future research.

It might be possible that during the pandemic, workers might be willing to work for lower wages, as a response to the worker losses in bargaining power and the increase in unemployment. This paper has weak evidence of a decline in the expected wages of job seekers; therefore, the question remains open.

Alternative data sources, as Google Trends presents a decline in the interest of internet users in topics like "jobs" in Costa Rica, especially during the lockdown period. As job search by online webpages gets relevance around the world, the dynamic of the trends on topic searched by users can contribute to understand deeper how the individuals react to shocks like the pandemic and the social distancing policies to alter their search behavior.

\section{REFERENCES}

Alon, T., Doepke, M., Olmstead-Rumsey, J., \& Tertilt, M. (2020, August). This Time it's Different: The Role of Women's Employment in a Pandemic Recession (NBER Working Paper Series, No. 27660). National Bureau of Economic Research. https://www.doi.org/10.3386/w27660

Basso, G., Boeri, T., Caiumi, A., \& Paccagnella, M. (2020). The New Hazardous Jobs and Worker Reallocation (OECD Social, Employment and Migration Working Papers, No 247). Organisation for Economic Cooperation and Development. https://www.doi. org/10.1787/400cf397-en

Bennedsen, M., Larsen, B., Schmutte, I., \& Scur, D. (2020). Preserving job matches during the COVID-19 pandemic: Firm-Level Evidence on the Role of Government Aid (GLO Discussion Paper 588). Global Labor Organization. http://hdl.handle.net/10419/221802

Betcherman, G., Giannakopoulos, N., Laliotis, I., Pantelaiou, I., Testaverde, M., \& Tzimas, G. (2020). Reacting Quickly and Protecting Jobs: The Short-Term Impacts of the COVID-19 Lockdown on the Greek Labor Market (Policy Research Working Paper 9356). http://hdl.handle. net/10986/34353

Borjas, G., \& Cassidy, H. (2020). The Adverse Effect of the COVID-19 Labor Market Shock on Inmigrant Employment (NBER Working Paper Series, No 13277). National Bureau of Economic Research. https://www.doi.org/10.3386/w27243

Brown, J., \& Matsa, D. A. (2020). Locked in by leverage: Job search during the housing crisis. Journal of Financial Economics, 136(3), 623-648. https://www.doi.org/10.1016/j. jfineco.2019.11.001

Bui, T. T. M., Button, P., \& Picciotti, E. G. (2020). Early Evidence on the Impact of Coronavirus Disease 2019 (COVID-19) and the Recession on Older Workers. Public Policy \& Aging Report, 30(4), 154-159. https://www.doi.org/10.1093/ppar/praa029

Central Bank of Costa Rica. (2020). Revision of the Macroeconomic Program 2020-21.

Chatterji, P., \& Li, Y. (2021). Effects of COVID-19 on school enrollment. Economics of Education Review, 83, Article 102128. https://www.doi.org/10.1016/j.econedurev.2021.102128 
Delaporte, I., \& Peña, W. (2020, May 6). Working from Home Under COVID-19: Who is Affected? Evidence From Latin American and Caribbean Countries. COVID Economics, 14, 200-229. https://cepr.org/content/covid-economics-vetted-and-real-time-papers-0

DeLoach, S. B., \& Kurt, M. (2013). Discouraging Workers: Estimating the Impacts of Macroeconomic Shocks on the Search Intensity of the Unemployed. Journal of Labor Research, 34(4), 433-454. https://www.doi.org/10.1007/s12122-013-9166-0

Dingel, J. I., \& Neiman, B. (2020). How many jobs can done at home? Journal of Public Economics, 189, Article 104235. https://www.doi.org/10.1016/j.jpubeco.2020.104235

Eichenbaum, M. S., Rebelo, S. \& Trabandt, M. (2020). The Macroeconomics of Epidemics. (NBER Working Paper Series, No. 26882). National Bureau of Economic Research. https://www.doi. org/10.3386/w26882

Elsby, M. W. L., Michaels, R., \& Ratner, D. (2015). The Beveridge Curve: A Survey. Journal of Economic Literature, 53(3), 571-630. https://www.doi.org/10.1257/jel.53.3.571

Faberman, R. J., \& Kudlyak, M. (2019). The intensity of Job Search and Search Duration. American Economic Journal: Macroeconomics, 11(3), 327-357. https://www.doi.org/10.1257/ mac. 20170315

Fetzer, T., Hensel, L., Hermle, J., \& Roth, C. (2020). Coronavirus Perceptions and Economic Anxiety. The Review of Economics and Statistics, 103(5), 968-978. https://www.doi.org/10.1162/ rest_a_00946

Forsythe, E., Kahn, L. B., Lange, F., \& Wiczer, D. (2020). Labor Demand in the Time of COVID-19: Evidence from Vacancy Postings and UI Claims. Journal of Public Economics, 189. Article 104238. https://www.doi.org/10.1016/j.jpubeco.2020.104238

Gomme, P., \& Lkhagvasuren, D. (2015). Worker search effort as an amplification mechanism. Journal of Monetary Economics, 75, 106-122. https://www.doi.org/10.1016/j. jmoneco.2015.02.002

Guerrieri, V., Lorenzoni, G., Straub, L., \& Werning, I. (2021). Macroeconomic Implications of COVID-19: Can Negative Supply Shocks cause Demand Shortages? American Economic Review (Forthcoming).

Hensvik, L., Le Barbachon, T., \& Rathelot, R. (2020, April). Which Jobs Are Done from Home? Evidence from the American TIme Use Survey (Discussion Paper Series, No. 13138). IZA Institute of Labor Economics. https:/www.iza.org/publications/dp/13138/which-jobs-aredone-from-home-evidence-from-the-american-time-use-survey

Hensvik, L., Le Barbanchon, T., \& Rathelot, R. (2021). Job Search during the COVID-19 Crisis. Journal of Public Economics, 194, 1-10. https://www.doi.org/10.1016/j.jpubeco.2020.104349

Hodrick, R. J., \& Prescott, E. C. (1997). Postwar U.S. Business Cycles: An Empirical Investigation. Journal of Money, Credit and Banking, 29(1), 1-16. https://www.doi.org/10.2307/2953682

Instituto Nacional de Estadística y Censos. (2018). Encuesta Nacional a Empresas: Metodología.

International Monetary Fund. (2020a). Policy Responses to COVID-19. https://www.imf.org/en/ Topics/imf-and-covid19/Policy-Responses-to-COVID-19\#C

International Monetary Fund. (2020b, June). World Economic Outlook Update. IMF.

Krueger, A. B., \& Mueller, A. (2010). Job search and unemployment insurance: New evidence from time use data. Journal of Public Economics, 94(3-4), 298-307. https://www.doi.org/10.1016/j. jpubeco.2009.12.001 
Krueger, A. B., \& Mueller, A. (Spring, 2011). Job Search, Emotional Well-Being, and Job Finding in a Period of Mass Unemployment: Evidence from High-Frequency Longitudinal Data [with Comments and Discussion]. Brooking Papers on Economic Activity, 1-81. https://www.jstor. org/stable/4122852

Lichand, G., Alberto Doria, C., Leal Neto, O., \& Cossi, J.. (2021). The Impacts of Remote Learning in Secondary Education during the Pandemic in Brazil (SSRN Scholarly Paper ID 3841775). Social Science Research Network. https://www.doi.org/10.2139/ssrn.3841775

Ministerio de Trabajo y Seguridad Social. (2020, July 17). Tercer Informe Mensual de Seguimiento a la ejecución del Bono Proteger. http://www.mtss.go.cr/elministerio/despacho/covid-19-mtss/ plan_proteger/archivos/tercer_informe_proteger.pdf

Musaddiq, T., Stange, K., Bacher-Hicks, A., \& Goodman, J (2021). The Pandemic's Effect on Demand for Public Schools, Homeschooling, and Private Schools. (NBER Working Paper Series, No 29262). National Bureau of Economic Research. https://www.doi.org/10.3386/ w29262

Pissarides, C. (2000). Equilibrium Unemployment Theory (2th ed.). MIT Press.

Saltiel, F. (2020, April 17). Who can work from home in developing countries? Covid Economics, 6, 104-118. https://cepr.org/content/covid-economics-vetted-and-real-time-papers-0

Shen, Y. S. (2020). Unexpected Shocks to Movement and Job Search: Evidence from COVID-19 Policies in Singapore using Google Data (ACI Policy Research Paper Series, No 4-2020). Asia Competitiveness Institute, National University of Singapore.

Yasenov, V. (2020, April). Who Can Work from Home? (Discussion Paper Series, No. 13197). IZA Institute of Labor Economics. https://www.iza.org/publications/dp/13197/who-can-workfrom-home

\section{DISCLAIMER}

The ideas expressed in this paper are those of the author and not necessarily represent the view of the Central Bank of Costa Rica. 


\section{9. Appendix}

\section{Appendix A. Data available from buscoempleocr.com}

Is the dataset representative for firms in Costa Rica? The data obtained from buscoempleocr includes daily information for the period January 2010 to the second week of June 2020. On average, it includes information for 1.488 firms per year.

To compare how representative is the dataset in comparison with the total of firms in the country, tables A2.1., A2.2. and A2.3. presents the distribution of the firms in buscomepleocr.com, compared with the Directory of Establishments from the National Institute of Statistics and Census (INEC), and the REVEC database, a directory of firms and persons created by the Central Bank of Costa Rica (BCCR) with administrative records.

In general, the sample size is considerably small in comparison with the total of firms in the Directory of Establishments, less than 4\%. By province, San José is overrepresented while Alajuela, Cartago and Limón are underrepresented (A1). By firm size, it seems that the medium and large firms are overrepresented (A2). Finally, by industry, agriculture and retail trade are underrepresented, while manufacturing and administrative services are overrepresented (A3).

\section{TABLE A1}

DISTRIBUTION OF FIRMS IN BUSCOEMPLEOCR, AND ON ADMINISTRATIVE RECORDS FROM NATIONAL INSTITUTE OF STATISTIC AND CENSUS AND CENTRAL BANK OF COSTA RICA BY PROVINCE.

\begin{tabular}{lcccccc}
\multicolumn{2}{c}{ Levels } & \multicolumn{7}{c}{ Composition } \\
\cline { 2 - 7 } & Buscoempleocr & INEC & BCCR & & \\
San José & 844 & 16,655 & 57,592 & Buscoempleocr & INEC & BCCR $^{\text {a/ }}$ \\
Alajuela & 204 & 8,246 & 23,699 & 13.7 & 41.1 & 43.3 \\
Cartago & 98 & 3,950 & 10,457 & 6.6 & 9.8 & 17.8 \\
Heredia & 189 & 4,364 & 14,964 & 12.7 & 10.8 & 11.3 \\
Guanacaste & 69 & 2,043 & 9,294 & 4.7 & 5.0 & 7.0 \\
Puntarenas & 59 & 2,972 & 9,800 & 4.0 & 7.3 & 7.4 \\
Limón & 21 & 1,808 & 6,981 & 1.4 & 4.5 & 5.3 \\
Unknown & 6 & 461 & 114 & 0.4 & 1.1 & 0.1 \\
Total & 1,488 & 40,499 & 132,899 & 100 & 100 & 100
\end{tabular}

a/ Data available for period 2012 - 2018. It includes firms and persons working in the industries as own employer. Source: : buscoempleocr.com, Central Bank of Costa Rica and National Institute of Statistics and Census. 
TABLE A2

DISTRIBUTION OF FIRMS IN BUSCOEMPLEOCR, AND ON ADMINISTRATIVE RECORDS FROM NATIONAL INSTITUTE OF STATISTIC AND CENSUS AND CENTAL BANK OF COSTA RICA BY FIRM SIZE.

\begin{tabular}{|c|c|c|c|c|c|c|}
\hline & \multicolumn{3}{|c|}{ Annual average number of firms $(2010-19)$} & \multicolumn{3}{|c|}{ Composition } \\
\hline & Buscoempleocr & INEC & $\mathrm{BCCR}^{\mathrm{a} /}$ & Buscoempleocr & INEC & $\mathrm{BCCR}^{\mathrm{a} /}$ \\
\hline 1 to $5^{1 /}$ & 773 & 26,538 & 105,620 & 52 & 66 & 79 \\
\hline 6 to $30^{2 /}$ & 300 & 9,181 & 16,728 & 20 & 23 & 13 \\
\hline 31 to 100 & 213 & 2,196 & 5,700 & 14 & 5 & 4 \\
\hline $\begin{array}{l}\text { More than } \\
100\end{array}$ & 202 & 1,082 & 4,851 & 14 & 3 & 4 \\
\hline Unknown & - & 1,502 & - & 0 & 4 & 0 \\
\hline Total & 1,488 & 40,499 & 132,899 & 100 & 100 & 100 \\
\hline
\end{tabular}

1/ For Buscoempleocr corresponds to the group "1 to 9" workers 2/ For Buscoempleocr corresponds to the group "10 to 30 " workers a/ Data available for period 2012 - 2018. It includes firms and persons working in the industries as own employer. Source: : buscoempleocr.com, Central Bank of Costa Rica and National Institute of Statistics and Census. 


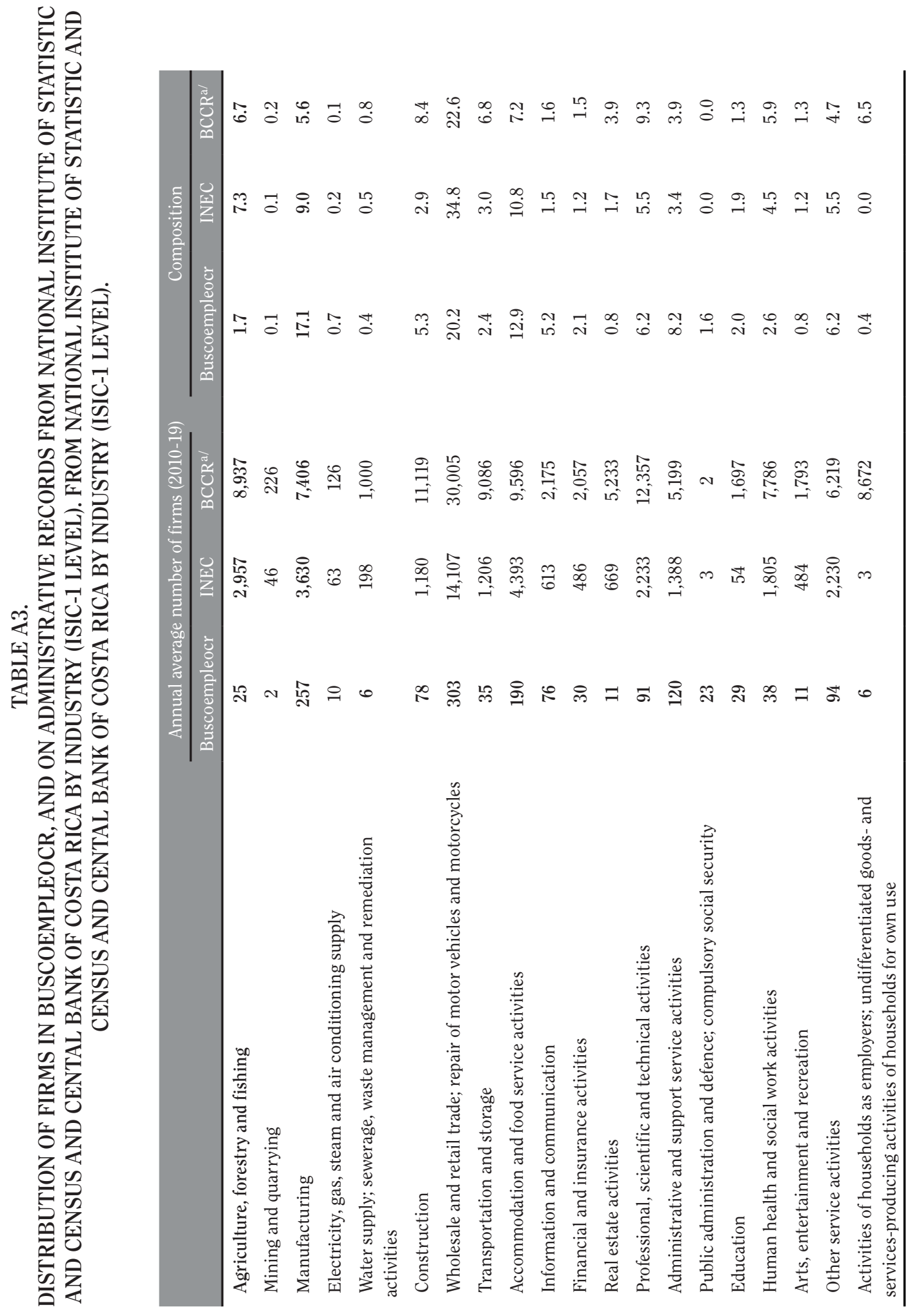




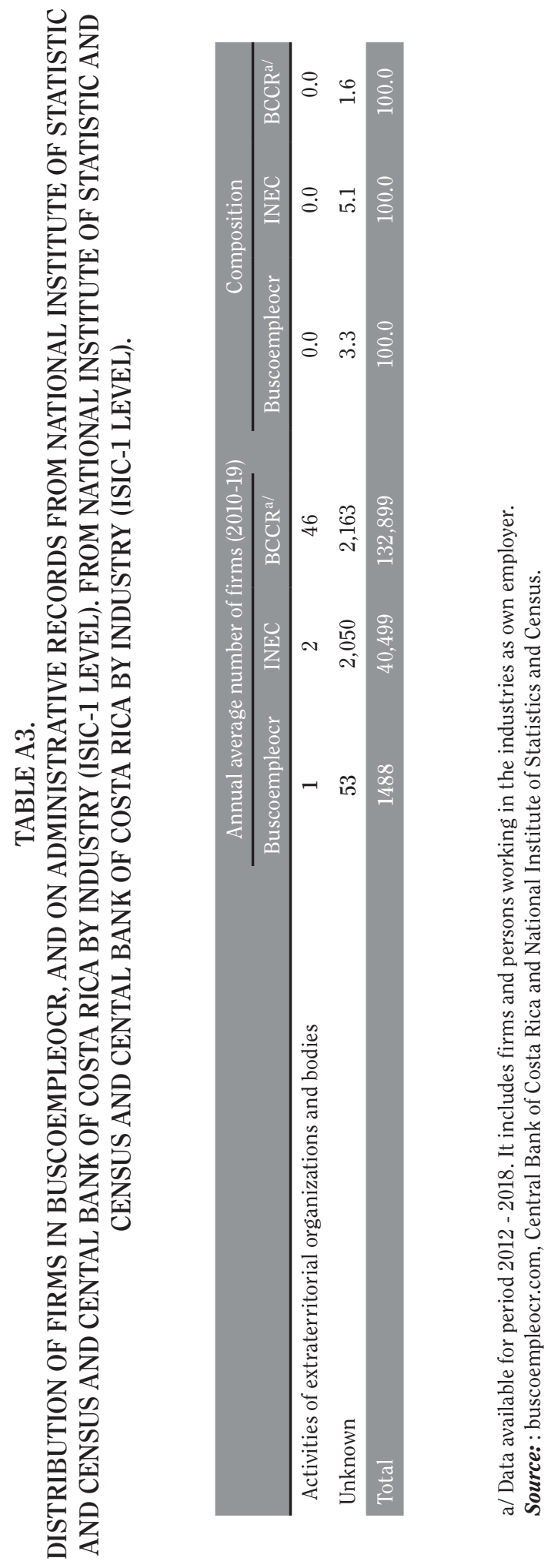


Data of vacancies. Data of vacancies is available since January 2010 to the second week of June 2020. The total dataset contains 253.667 vacancies, each of one contains information about the date when the vacant is posted, location, economic activity of the firm who is hiring, occupation, education required, languages required, other knowledge required, range of age, among others.

FIGURE A1

MONTHLY VACANCIES POSTED IN WWW.BUSCOEMPLEOCR.COM

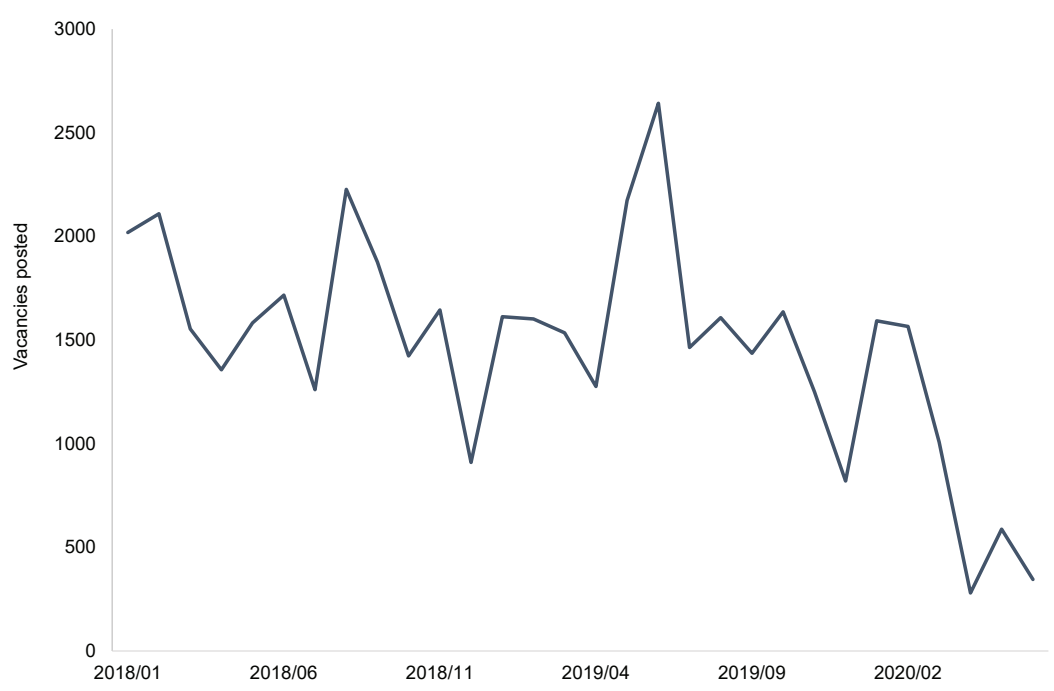

Data about job applicants. Information from January 2010 to Jun 2020 of the 12.904 job seekers who upload their CV to apply for jobs in buscoempleocr.com is available in the dataset. It is worth to say that while in 2019 the total of job seekers was 2.242, in 2020 the number of applicants at the second week of June has increased to 5.745. The dataset contains information about the date when the person uploaded their CV, gender, location, occupation desired (maximum 5 occupations) and education level.

Table A4. present the distribution of the data of the average 2010-2019 of job seekers by groups of age, gender and education level and the distribution of unemployed workers from the Employment Survey published by the National Institute of Statistics and Census. The data of buscoempleocr present differences in comparison with the distribution of unemployed workers, therefore it is not a representative sample. 
TABLE A4

DISTRIBUTION OF JOB SEEKERS IN BUSCOEMPLEOCR, AND UNEMPLOYED WORKERS FROM NATIONAL INSTITUTE OF STATISTIC AND CENSUS.

\begin{tabular}{|c|c|c|c|c|c|}
\hline \multirow[b]{2}{*}{ Groups of age } & \multicolumn{2}{|c|}{ buscoempleocr ${ }^{1 /}$} & \multicolumn{2}{|c|}{ INEC $^{2 /}$} & \\
\hline & Applicants & $\%$ & Unemployed & $\%$ & \\
\hline 15 to 24 & 174.4 & 24.9 & & 91806 & 40.1 \\
\hline 25 to 34 & 319.7 & 45.6 & & 62138 & 27.2 \\
\hline 35 to 44 & 128.9 & 18.4 & & 33269 & 14.5 \\
\hline 45 to 59 & 72.4 & 10.3 & & 33208 & 14.5 \\
\hline 60 or more & 6 & 0.9 & & 8288 & 3.6 \\
\hline Unknown & 0.1 & 0.0 & & 34 & 0.0 \\
\hline Total & 701.5 & 100.0 & & 228742 & 100.0 \\
\hline \multicolumn{6}{|l|}{ Gender } \\
\hline Female & 318.5 & 44.2 & & 123521 & 54.0 \\
\hline Male & 383 & 55.8 & & 105221 & 46.0 \\
\hline Total & 701.5 & 100 & & 228742 & 100 \\
\hline \multicolumn{6}{|l|}{ Education Level } \\
\hline $\begin{array}{l}\text { Primary } \\
\text { education } \\
\text { (insufficient) }\end{array}$ & 3.1 & 0.5 & & 91806 & 10.2 \\
\hline $\begin{array}{l}\text { Primary } \\
\text { education }\end{array}$ & 25.2 & 3.6 & & 62138 & 21.1 \\
\hline $\begin{array}{l}\text { Secondary } \\
\text { education } \\
\text { (insufficient) }\end{array}$ & 97.1 & 14.2 & & 33269 & 32.5 \\
\hline $\begin{array}{l}\text { Secondary } \\
\text { education }\end{array}$ & 248.9 & 33.5 & & 33208 & 18.6 \\
\hline $\begin{array}{l}\text { College education } \\
\text { (insufficient) }\end{array}$ & 98.7 & 14.7 & & 8288 & 6.5 \\
\hline College education & 228.3 & 33.5 & & 34 & 11.1 \\
\hline Unknown & 0.2 & 0.0 & & - & 0.0 \\
\hline Total & 701.5 & 100.0 & & 228742 & 100 \\
\hline
\end{tabular}

1/ Average data for $2010-2019$.

2/ Average data for $2016-2019$.

Source: : buscoempleocr.com, Central Bank of Costa Rica and National Institute of Statistics and Census. 
Appendix B. Validation of the assumption of "common trends" for the Differences in Differences estimations.

The method of Differences in Differences is used, is normally implemented under the assumption of "common trends". This implies that before a treatment is implemented, the trend of treatment group and control group were the same. Under this assumption, both groups exhibit the same "behavior", and therefore, when a treatment is applied to a group, we can compare its trend after and estimated the effect on the treated by comparing with the control group. The common trends assumption allows to infer that in absence of the treatment, both groups will present the same behavior.

In the context of this paper, the assumption of common trends implies that in the absence of the pandemic, the trend of the vacancies posted in 2019 and 2020 should be the same, therefore, after the begin of the pandemic, the change in the trend of vacancies posted relative to the trend of vacancies in 2019 can be interpreted as the effect of the "treatment". The same approach is used to estimate the effect of the pandemic on the job search intensity.

One way to check that the trends of 2019 and 2020 are the same in the period before the start of the pandemic (weeks 1 to 10), is to assume a breakpoint occurred on a period between weeks 1 and 10 , estimate the regressions and if the estimate is not significant, then the assumption is valid.

Table B1 presents the placebo tests estimated effect of regression (1) using data for 2019 and 2020 in the period between week 1 and week 10, and assuming breakpoints in weeks 3,5 and 7 in comparison with the estimates presented in the results section, using week 10 as a breakpoint and the data from week 1 to week 24 . As it can be noticed, the estimates for the placebo tests are not significant. The same results are founded for the vacancies posted by industries, occupations, and locations (tables B2 to B5). Similarly, the estimates for the search intensity indicators are not significant, as it can be confirmed in table B6. In sum, the assumption of common trends is valid, which suggest that the estimates presented in this paper are unbiased.

TABLE B1

ESTIMATED EFFECTS ON VACANCY POSTING ASSUMING BREAKPOINTS IN WEEKS 3, 5 AND 7

\begin{tabular}{|c|c|c|c|c|c|c|c|c|}
\hline \multicolumn{9}{|c|}{ Week of Breakpoint } \\
\hline & \multicolumn{2}{|c|}{ Week 3} & \multicolumn{2}{|c|}{ Week 5} & \multicolumn{2}{|c|}{ Week 7} & \multicolumn{2}{|c|}{ Week $10^{1}$} \\
\hline & Beta & $\begin{array}{l}\text { Robust } \\
\text { Std. Error }\end{array}$ & Beta & $\begin{array}{c}\text { Robust Std. } \\
\text { Error }\end{array}$ & Beta & $\begin{array}{c}\text { Robust Std. } \\
\text { Error }\end{array}$ & Beta & $\begin{array}{c}\text { Robust Std. } \\
\text { Error }\end{array}$ \\
\hline Total & -0.491 & $(0.229)$ & -0.072 & $(0.263)$ & 0.167 & $(0.229)$ & 0.167 & $(0.229)$ \\
\hline
\end{tabular}

1/ Corresponds to the estimated effect presented in the results section.

Source: : Author's estimates with data from buscoempleocr 


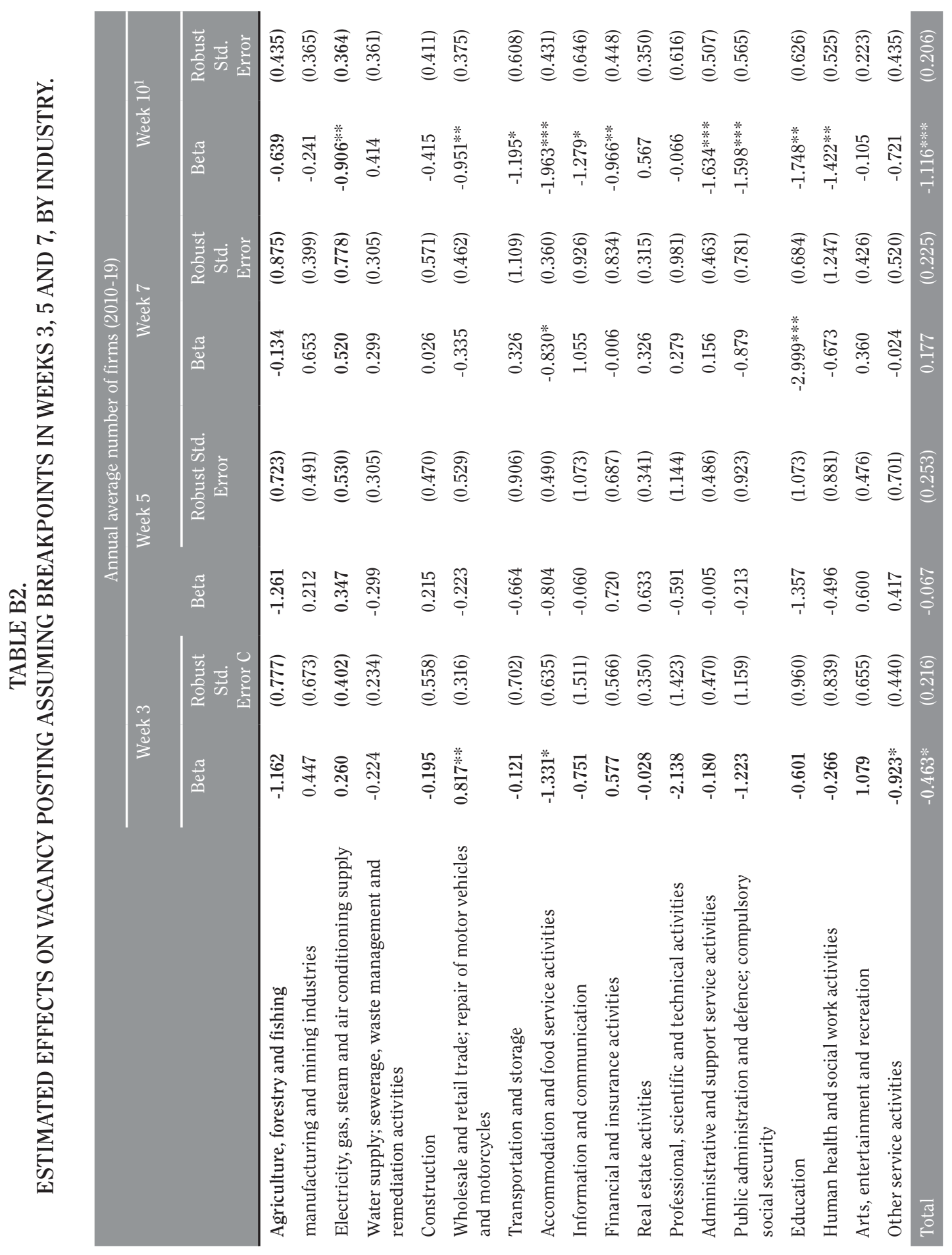




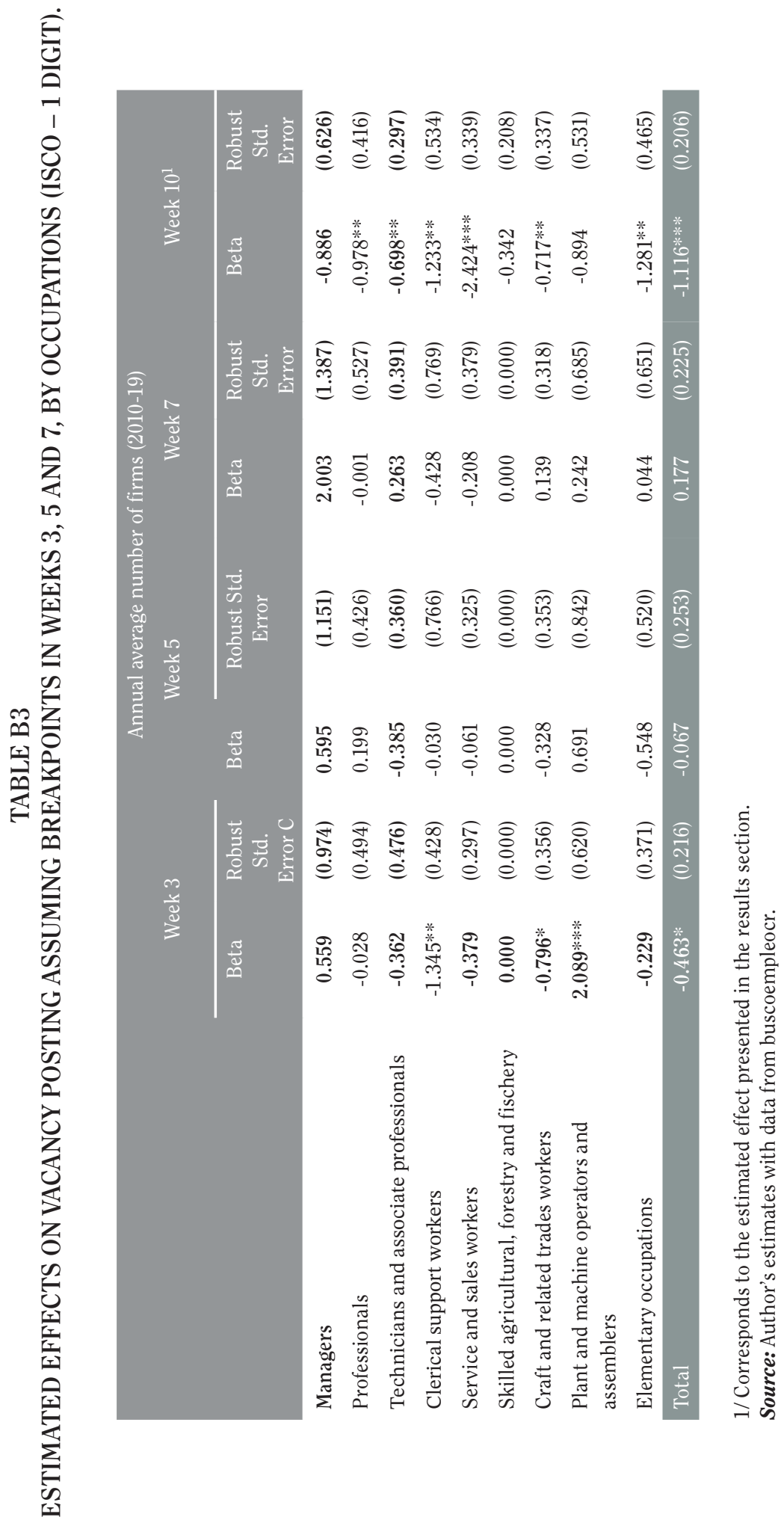




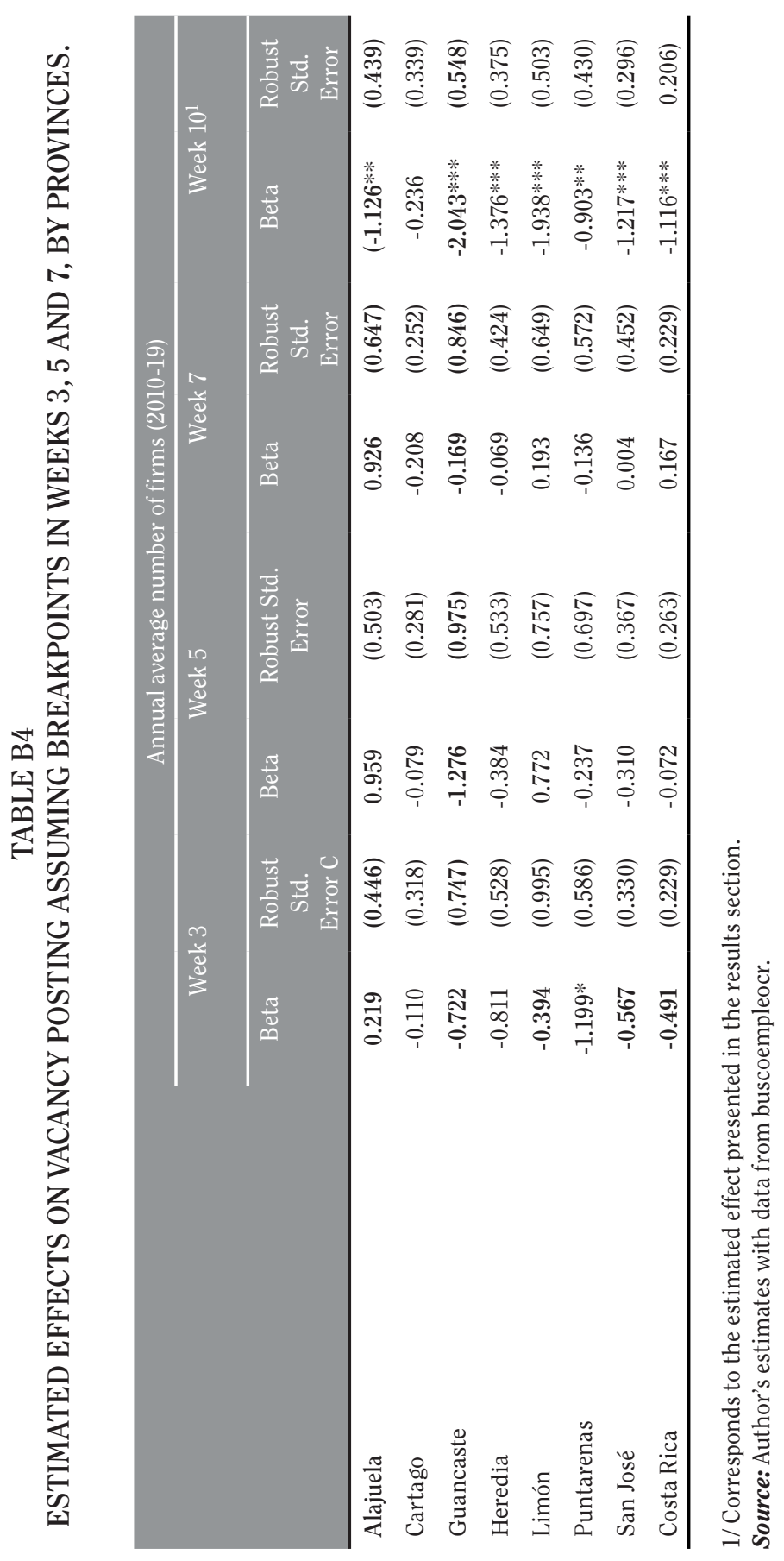




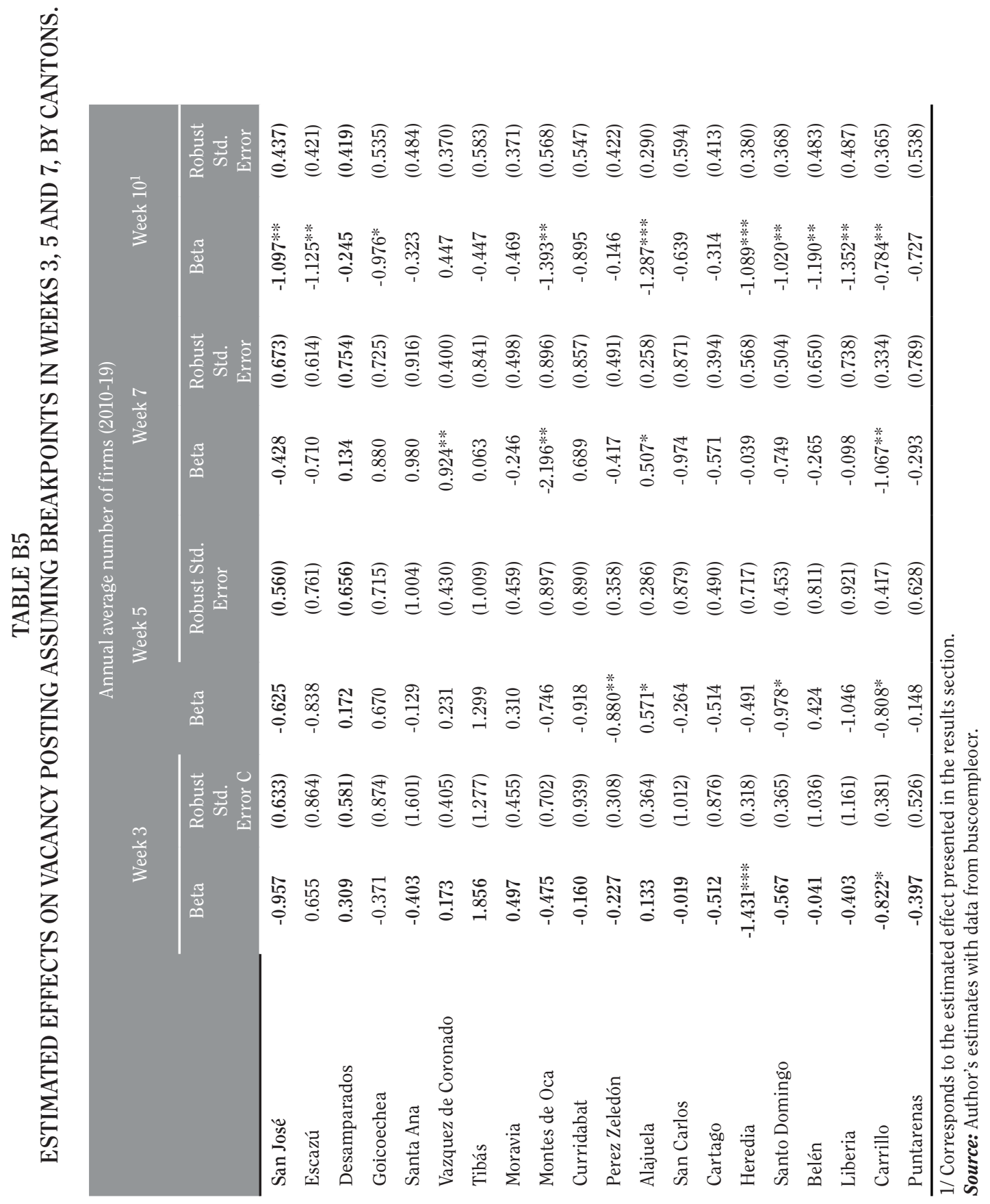




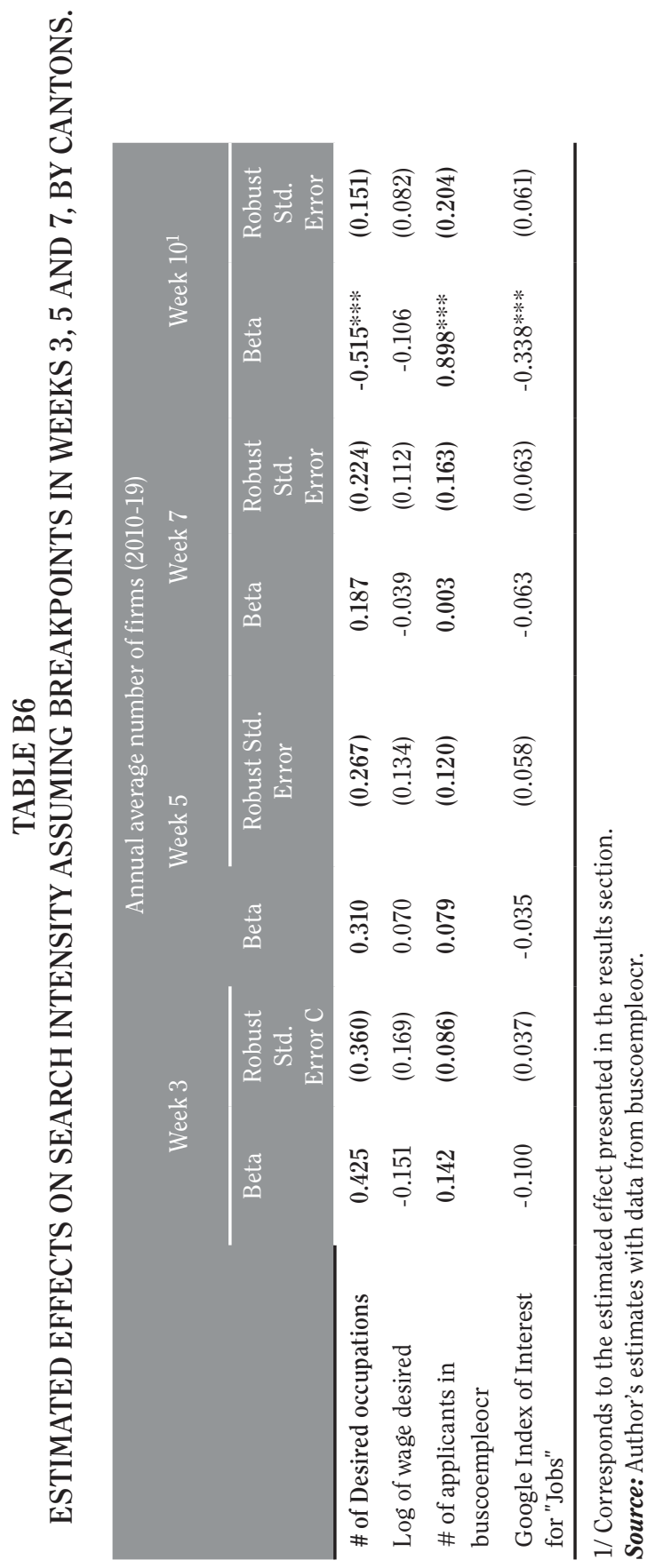




\section{APPENDIX C. DIFFERENCES IN DIFFERENCES ESTIMATIONS OF THE EFFECT OF LOCKDOWN IN THE INFLOW OF VACANCIES POSTED IN BUSCOEMPLEOCR BY OCCUPATION AT ISCO 2 DIGITS.}

\begin{tabular}{|c|c|c|c|c|}
\hline ISCO - 2 digits & Beta & $\begin{array}{l}\text { Robust } \\
\text { Std. Error }\end{array}$ & $\begin{array}{c}\Delta \text { inflow of } \\
\text { vacancies }(\%)\end{array}$ & R-Squared \\
\hline Personal Services Workers & $-2.095^{* * *}$ & $(0.359)$ & -87.7 & 0.805 \\
\hline Sales Workers & $-1.598 * * *$ & $(0.402)$ & -79.8 & 0.751 \\
\hline Food Preparation Assistants & $-1.562 * * *$ & $(0.327)$ & -79.0 & 0.788 \\
\hline Electrical and Electronic Trades Workers & $-1.370^{* * * *}$ & $(0.420)$ & -74.6 & 0.675 \\
\hline Protective Services Workers & $-1.341^{*}$ & $(0.679)$ & -73.8 & 0.568 \\
\hline Cleaners and Helpers & $-1.292 * *$ & $(0.472)$ & -72.5 & 0.607 \\
\hline Drivers and Mobile Plant Operators & $-1.271^{* *}$ & $(0.569)$ & -71.9 & 0.580 \\
\hline $\begin{array}{l}\text { Business and Administration Associate } \\
\text { Professionals }\end{array}$ & $-1.180^{* * *}$ & $(0.338)$ & -69.3 & 0.681 \\
\hline General and Keyboard Clerks & $-1.089^{* * *}$ & $(0.348)$ & -66.3 & 0.818 \\
\hline Customer Services Clerks & -1.082 & $(0.754)$ & -66.1 & 0.664 \\
\hline Chief Executives, Senior Officials and Legislators & -0.965 & $(0.577)$ & -61.9 & 0.591 \\
\hline $\begin{array}{l}\text { Food Processing, Woodworking, Garment and } \\
\text { Other Craft and Related Trades Workers }\end{array}$ & $-0.959^{*}$ & $(0.492)$ & -61.7 & 0.567 \\
\hline Business and Administration Professionals & $-0.914^{* * *}$ & $(0.314)$ & -59.9 & 0.802 \\
\hline Hospitality, Retail and Other Services Managers & $-0.761^{* * *}$ & $(0.202)$ & -53.3 & 0.723 \\
\hline Refuse Workers and Other Elementary Workers & -0.744 & $(0.565)$ & -52.5 & 0.522 \\
\hline Numerical and Material Recording Clerks & $-0.732^{*}$ & $(0.406)$ & -51.9 & 0.610 \\
\hline Personal Care Workers & -0.672 & $(0.548)$ & -48.9 & 0.687 \\
\hline Metal, Machinery and Related Trades Workers & -0.647 & $(0.416)$ & -47.6 & 0.573 \\
\hline Other Clerical Support Workers & $-0.573^{* *}$ & $(0.233)$ & -43.6 & 0.610 \\
\hline $\begin{array}{l}\text { Information and Communications Technology } \\
\text { Professionals }\end{array}$ & -0.483 & $(0.436)$ & -38.3 & 0.708 \\
\hline $\begin{array}{l}\text { Legal, Social, Cultural and Related Associate } \\
\text { Professionals }\end{array}$ & -0.467 & $(0.448)$ & -37.3 & 0.594 \\
\hline Education Technicians & -0.453 & $(0.525)$ & -36.4 & 0.521 \\
\hline Science and Engineering Professionals & -0.445 & $(0.681)$ & -35.9 & 0.630 \\
\hline Teaching Professionals & -0.430 & $(0.710)$ & -34.9 & 0.510 \\
\hline Science and Engineering Associate Professionals & -0.394 & $(0.297)$ & -32.6 & 0.675 \\
\hline Production and Specialized Services Managers & -0.386 & $(0.349)$ & -32.0 & 0.528 \\
\hline Agricultural, Forestry and Fishery Labourers & -0.339 & $(0.478)$ & -28.8 & 0.468 \\
\hline $\begin{array}{l}\text { Labourers in Mining, Construction, } \\
\text { Manufacturing and Transport }\end{array}$ & -0.305 & $(0.721)$ & -26.3 & 0.408 \\
\hline Market-oriented Skilled Agricultural Workers & -0.295 & $(0.219)$ & -25.5 & 0.529 \\
\hline Health Associate Professionals & -0.269 & $(0.414)$ & -23.6 & 0.450 \\
\hline Legal, Social and Cultural Professionals & -0.249 & $(0.544)$ & -22.0 & 0.644 \\
\hline
\end{tabular}




\begin{tabular}{|c|c|c|c|c|}
\hline ISCO - 2 digits & Beta & $\begin{array}{l}\text { Robust } \\
\text { Std. Error }\end{array}$ & $\begin{array}{c}\Delta \text { inflow of } \\
\text { vacancies }(\%)\end{array}$ & R-Squared \\
\hline $\begin{array}{l}\text { Building and Related Trades Workers (excluding } \\
\text { Electricians) }\end{array}$ & -0.143 & $(0.387)$ & -13.3 & 0.677 \\
\hline Street and Related Sales and Services Workers & -0.125 & $(0.269)$ & -11.8 & 0.490 \\
\hline Information and Communications Technicians & -0.059 & $(0.599)$ & -5.7 & 0.552 \\
\hline Health Professionals & -0.056 & $(0.370)$ & -5.4 & 0.445 \\
\hline Assemblers & -0.041 & $(0.208)$ & -4.0 & 0.593 \\
\hline Stationary Plant and Machine Operators & 0.078 & $(0.280)$ & 8.1 & 0.664 \\
\hline Handicraft and Printing Workers & 0.443 & $(0.394)$ & 55.7 & 0.719 \\
\hline Administrative and Commercial Managers & 0.596 & $(0.424)$ & 81.5 & 0.663 \\
\hline Other technicians & 0.650 & $(0.516)$ & 91.6 & 0.584 \\
\hline
\end{tabular}

$* * * \mathrm{p}<0.01, * * \mathrm{p}<0.05, * \mathrm{p}<0.1$

Notes: Models estimated by Differences in Differences, following the specification presented in equation 1. Each row in the table corresponds to a model estimated by each type of occupations at ISCO 2 digits, including week and year fixed effects. Source: Author's estimates with data from buscoempleocr. 


\section{APPENDIX D \\ COMPOSITION OF VACANCIES POSTED IN BUSCOEMPLEOCR BY CANTON AND INDUSTRY AVERAGE COMPOSITION FOR 2015 - 2019.}
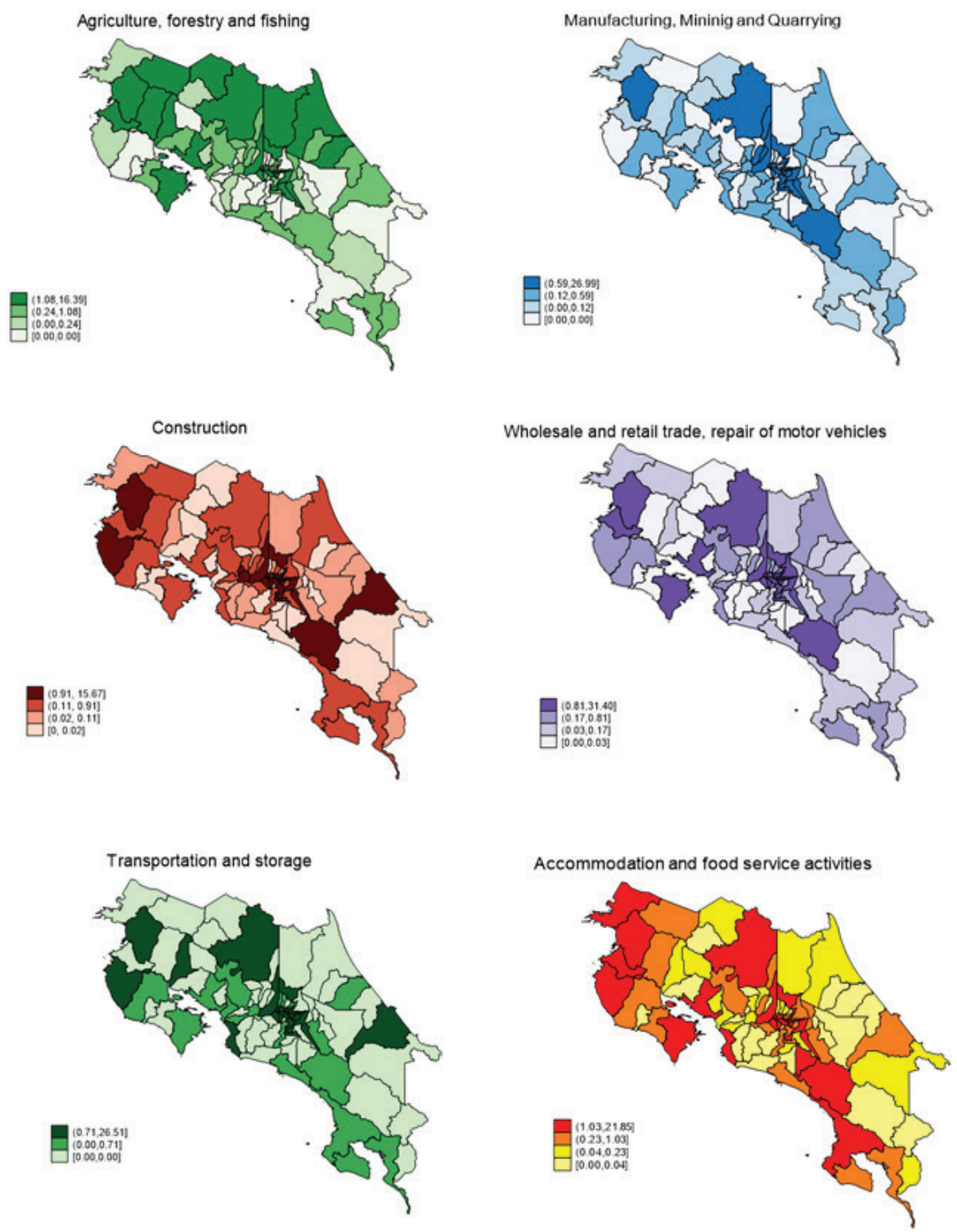


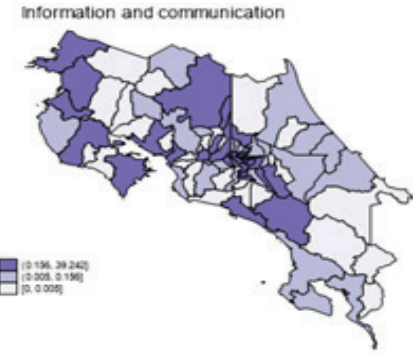

Protessional, Administrative and support services activities

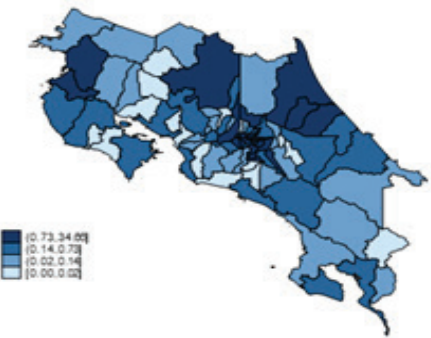

Education, Human Health and Social Work Activities

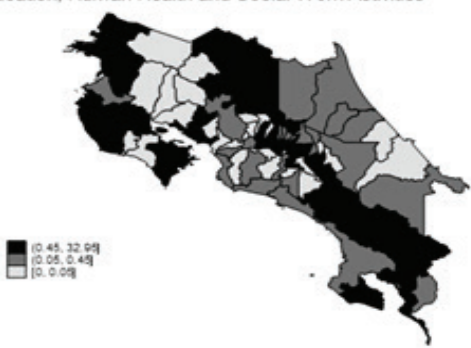

Electricity. gas, air conditioning and Water Supply

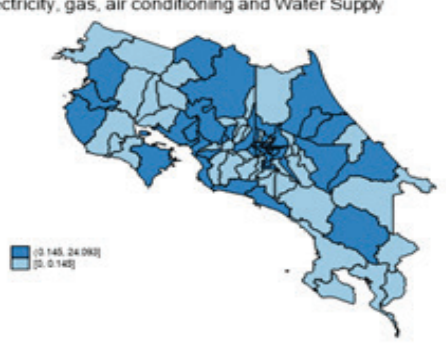

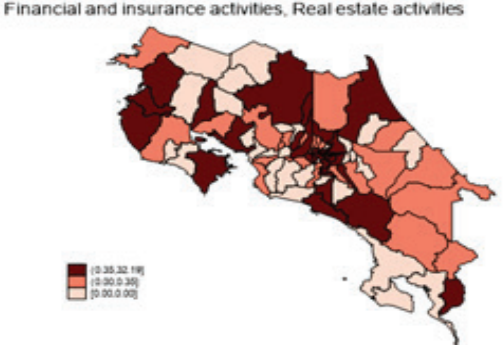

Public Administration and Defence; compulsory Social Security

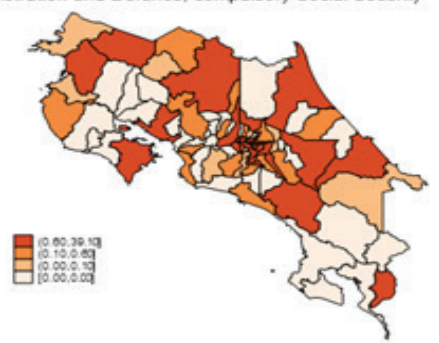

Other Services

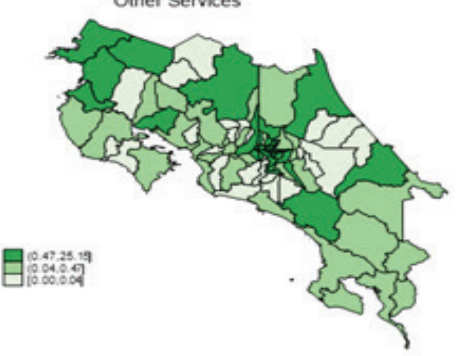


Appendix E. Differences in Differences estimations of the effect of the pandemic in the inflow of vacancies posted in buscoempleocr by cantons.

\section{TABLE E1 \\ COMPOSITION OF VACANCIES POSTED FROM WEEKS 1 TO 24 IN BUSCOEMPLEOCR BY CANTON IN 2019 AND 2020.}

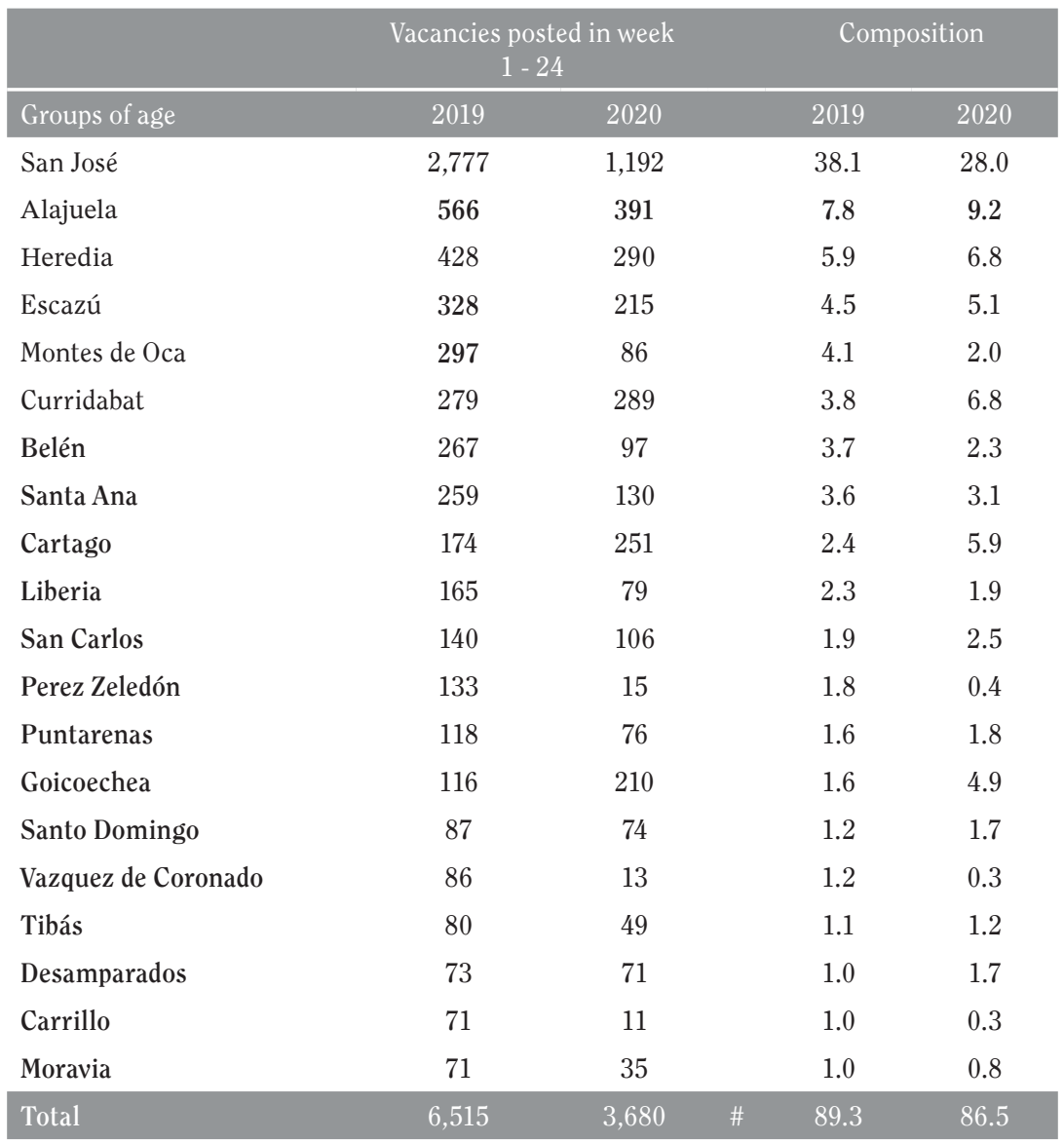

Source: Author's estimates with data from buscoempleocr. 
TABLE E2

ESTIMATED EFFECT ON THE INFLOW OF VACANCIES BEFORE AND AFTER WEEK 10 IN 2020, RELATIVE TO THE PREVIOUS YEAR BY CANTONS.

\begin{tabular}{|c|c|c|c|c|}
\hline \multirow[b]{2}{*}{ Groups of age } & \multicolumn{2}{|c|}{$\begin{array}{l}\text { Vacancies posted in week } \\
1-24\end{array}$} & \multicolumn{2}{|c|}{ Composition } \\
\hline & 2019 & 2020 & 2019 & 2020 \\
\hline Montes de Oca & $-1.393^{* *}$ & $(0.568)$ & -75.2 & 0.682 \\
\hline Liberia & $-1.352^{* *}$ & $(0.487)$ & -74.1 & 0.615 \\
\hline Alajuela & $-1.287^{* * *} *$ & $(0.290)$ & -72.4 & 0.773 \\
\hline Belén & $-1.190 * *$ & $(0.483)$ & -69.6 & 0.731 \\
\hline Escazú & $-1.125^{* * *}$ & $(0.421)$ & -67.5 & 0.722 \\
\hline San José & $-1.097 * *$ & $(0.437)$ & -66.6 & 0.717 \\
\hline Heredia & $-1.089^{* * *}$ & $(0.380)$ & -66.3 & 0.789 \\
\hline Santo Domingo & $-1.020^{* *}$ & $(0.368)$ & -63.9 & 0.676 \\
\hline Goicoechea & $-0.976^{*}$ & $(0.535)$ & -62.3 & 0.443 \\
\hline Curridabat & -0.895 & $(0.547)$ & -59.1 & 0.699 \\
\hline Carrillo & $-0.784^{* *}$ & $(0.365)$ & -54.3 & 0.69 \\
\hline Puntarenas & -0.727 & $(0.538)$ & -51.7 & 0.548 \\
\hline San Carlos & -0.639 & $(0.594)$ & -47.2 & 0.458 \\
\hline Moravia & -0.469 & $(0.371)$ & -37.4 & 0.567 \\
\hline Tibás & -0.447 & $(0.583)$ & -36.0 & 0.511 \\
\hline Santa Ana & -0.323 & $(0.484)$ & -27.6 & 0.569 \\
\hline Cartago & -0.314 & $(0.413)$ & -26.9 & 0.519 \\
\hline Desamparados & -0.245 & $(0.419)$ & -21.7 & 0.579 \\
\hline Perez Zeledón & -0.146 & $(0.422)$ & -13.6 & 0.674 \\
\hline Vazquez de Coronado & 0.447 & $(0.370)$ & 56.4 & 0.577 \\
\hline
\end{tabular}

$* * * \mathrm{p}<0.01, * * \mathrm{p}<0.05, * \mathrm{p}<0.1$

Notes: Models estimated by Differences in Differences, following the specification presented in equation 1 . Each row in the table corresponds to a model estimated by each canton, including week and year fixed effects.

Source: : Author's estimates with data from buscoempleocr

Este artículo se encuentra disponible mediante la licencia Creative Commons Reconocimiento-NoComercial-SinObraDerivada 3.0 Costa Rica. Para mayor información escribir a revista.iice@ucr.ac.cr. 